\title{
The Use of Insecticides to Manage the Western Corn Rootworm, Diabrotica virgifera virgifera, LeConte: History, Field-Evolved Resistance, and Associated Mechanisms
}

\author{
Lance J. Meinke $^{1, *}$, Dariane Souza ${ }^{2}(1)$ and Blair D. Siegfried ${ }^{2}$ \\ 1 Department of Entomology, University of Nebraska, Lincoln, NE 68583, USA \\ 2 Entomology and Nematology Department, University of Florida, Gainesville, FL 32611, USA; \\ dariane.souza@ufl.edu (D.S.); bsiegfried1@ufl.edu (B.D.S.) \\ * Correspondence: lmeinke1@unl.edu
}

Citation: Meinke, L.J.; Souza, D.; Siegfried, B.D. The Use of Insecticides to Manage the Western Corn Rootworm, Diabrotica virgifera virgifera, LeConte: History, Field-Evolved Resistance, and Associated Mechanisms. Insects 2021, 12, 112. https://doi.org/10.3390/ insects12020112

Academic Editor: Katarina M. Mikac Received: 8 January 2021

Accepted: 25 January 2021

Published: 28 January 2021

Publisher's Note: MDPI stays neutral with regard to jurisdictional claims in published maps and institutional affiliations.

Copyright: (C) 2021 by the authors Licensee MDPI, Basel, Switzerland This article is an open access article distributed under the terms and conditions of the Creative Commons Attribution (CC BY) license (https:// creativecommons.org/licenses/by/ $4.0 /)$.
Simple Summary: The structure of agricultural enterprises in the western United States Corn Belt (large irrigated monocultures, continuous planting of maize, strong aerial pesticide application and livestock industries) has led to a tradition of extensive insecticide use over time to manage the western corn rootworm, Diabrotica virgifera virgifera LeConte (Dvv) a key insect pest of maize. Dvv damages maize roots, which can cause maize plant instability, reduced plant growth, and significant yield loss. Long-term insecticide use has contributed to Dvv becoming resistant to cyclodiene, organophosphate, carbamate, and pyrethroid insecticides since the 1950s. This paper reviews the historical and current use of insecticides in Dvv management programs and Dvv adaptation to insecticide use. Currently, insecticides have a reduced role in Dvv management programs but are still used as complementary tactics with other management approaches. Past history suggests that the probability of selecting for resistance to any future Dvv control technology will be high if it is not used within an integrated pest management framework with other tactics.

Abstract: The western corn rootworm, Diabrotica virgifera virgifera LeConte (Dvv) is a significant insect pest of maize in the United States (U.S.). This paper reviews the history of insecticide use in Dvv management programs, Dvv adaptation to insecticides, i.e., field-evolved resistance and associated mechanisms of resistance, plus the current role of insecticides in the transgenic era. In the western U.S. Corn Belt where continuous maize is commonly grown in large irrigated monocultures, broadcast-applied soil or foliar insecticides have been extensively used over time to manage annual densities of Dvv and other secondary insect pests. This has contributed to the sequential occurrence of Dvv resistance evolution to cyclodiene, organophosphate, carbamate, and pyrethroid insecticides since the 1950s. Mechanisms of resistance are complex, but both oxidative and hydrolytic metabolism contribute to organophosphate, carbamate, and pyrethroid resistance facilitating cross-resistance between insecticide classes. History shows that Dvv insecticide resistance can evolve quickly and may persist in field populations even in the absence of selection. This suggests minimal fitness costs associated with Dvv resistance. In the transgenic era, insecticides function primarily as complementary tools with other Dvv management tactics to manage annual Dvv densities/crop injury and resistance over time.

Keywords: chemical control; pest management; insecticide metabolism; Diabrotica virgifera virgifera; insecticide resistance

\section{Introduction}

The western corn rootworm, Diabrotica virgifera virgifera LeConte (Dvv) is a galerucerine Chrysomelid beetle (Figure 1A) that is one of the most significant insect pests of maize (Zea mays L.) in the United States (U.S.). Annually, this species is responsible for over 
$\$ 1$ billion in control costs and yield losses [1,2]. Similar to other Diabrotica species, the larvae are root feeders and adults feed on above-ground plant tissues [3,4]. Dvv larvae survive only on a small number of grass species [3-8] while adults feed primarily on pollen and reproductive tissues of a variety of plants [9,10]. Maize is the primary Dvv host in modern agroecosystems [10,11] and is strongly attractive to wild-type adult Dvv [12-14]. The initial Dvv species description was made in 1868 from collections made in what today is Wallace Co., KS [15] but phylogenetic research points toward a species origin in Mexico or Central America [16,17]. It has been hypothesized that Dvv may have survived at low densities on native grasses such as western wheatgrass, Pascopyrum smithii (Rydb.) at the time of initial discovery [7]. The pheromone of Dvv is very efficient at ultra-low levels, which supports the low Dvv density hypothesis before adaptation to maize monocultures [11]. It is unclear when Dvv arrived in what today is the southwestern U.S. but records document that Dvv did not occur east of western Kansas, Colorado, and southwestern Nebraska, U.S. prior to the 1920s [18].
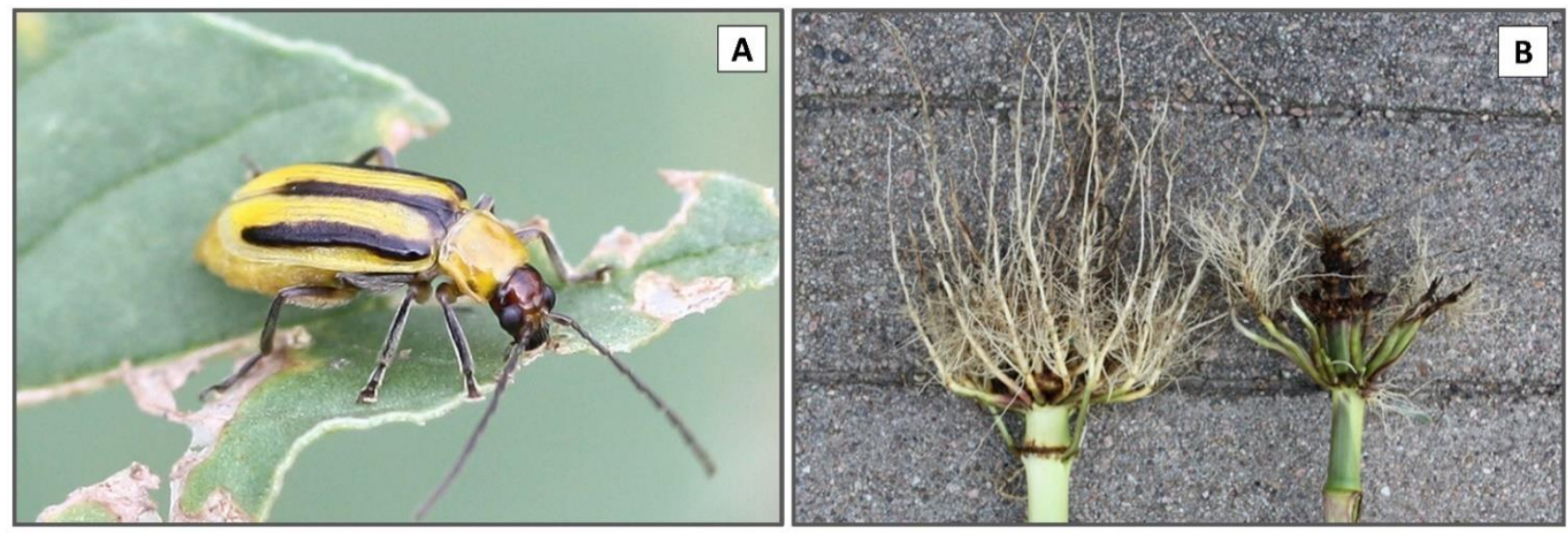

Figure 1. (A) Adult Diabrotica virgifera virgifera LeConte; (B) example of severe root injury from Diabrotica virgifera virgifera LeConte (Dvv) larval feeding that can occur when Dvv larval density is high (right) versus uninjured root (left); photos by L. J. Meinke.

Dvv was first recorded feeding on maize roots at Ft. Collins, Co. in 1909 [19]. Annual rotation from maize to a crop that would not support Dvv larval survival was the recommended Dvv management tactic as early as 1930 in southwestern Nebraska [20,21] but the profitability of maize led some growers to start planting continuous maize (maize planted for $\geq 2$ years in one location). As agriculture developed in western areas of Nebraska during the 1930s sporadic reports of larval Dvv injury were reported in continuous maize [20-22]. By the 1940s, Dvv injury to continuous maize (Figure 1B) in central Nebraska was common and was facilitated in part by the introduction of irrigation systems and synthetic fertilizer [23-26]. This agricultural system became very profitable and helped meet the demand for maize from a growing confined livestock industry. Continuous maize provided optimal conditions for the build-up of Dvv densities, increasing larval injury and greater adult dispersal from infested fields [18]. The large monocultures of continuous maize may have been the bridge needed to jump-start the fairly rapid range expansion that progressed through the U.S. Corn Belt reaching NJ, USA by the 1980's $[18,27]$.

The emergence of Dvv as a major insect pest coincided with the post-World War II emergence of agrochemical companies that synthesized and manufactured synthetic organic insecticides. The need for Dvv control in continuous maize created a niche that developed into a large insecticide market in the U.S. Corn Belt [28]. Evaluation of insecticide efficacy targeting larvae (soil insecticides) or adults (foliar applications) was a major focus of both industry and academia in the 1940s-1990s [25,29-38]. Seed treatments and transgenic plants that express proteins that are toxic to Dvv (plant incorporated protectants) were 
introduced and widely adopted in the 2000s, which reduced the role of insecticides as management tactics in continuous maize [26,39-41]. This paper reviews the history of insecticide use in Dvv management programs, Dvv adaption to insecticides (Figure 2), i.e., field-evolved resistance and associated mechanisms of resistance, plus the current role of insecticides in the transgenic era.

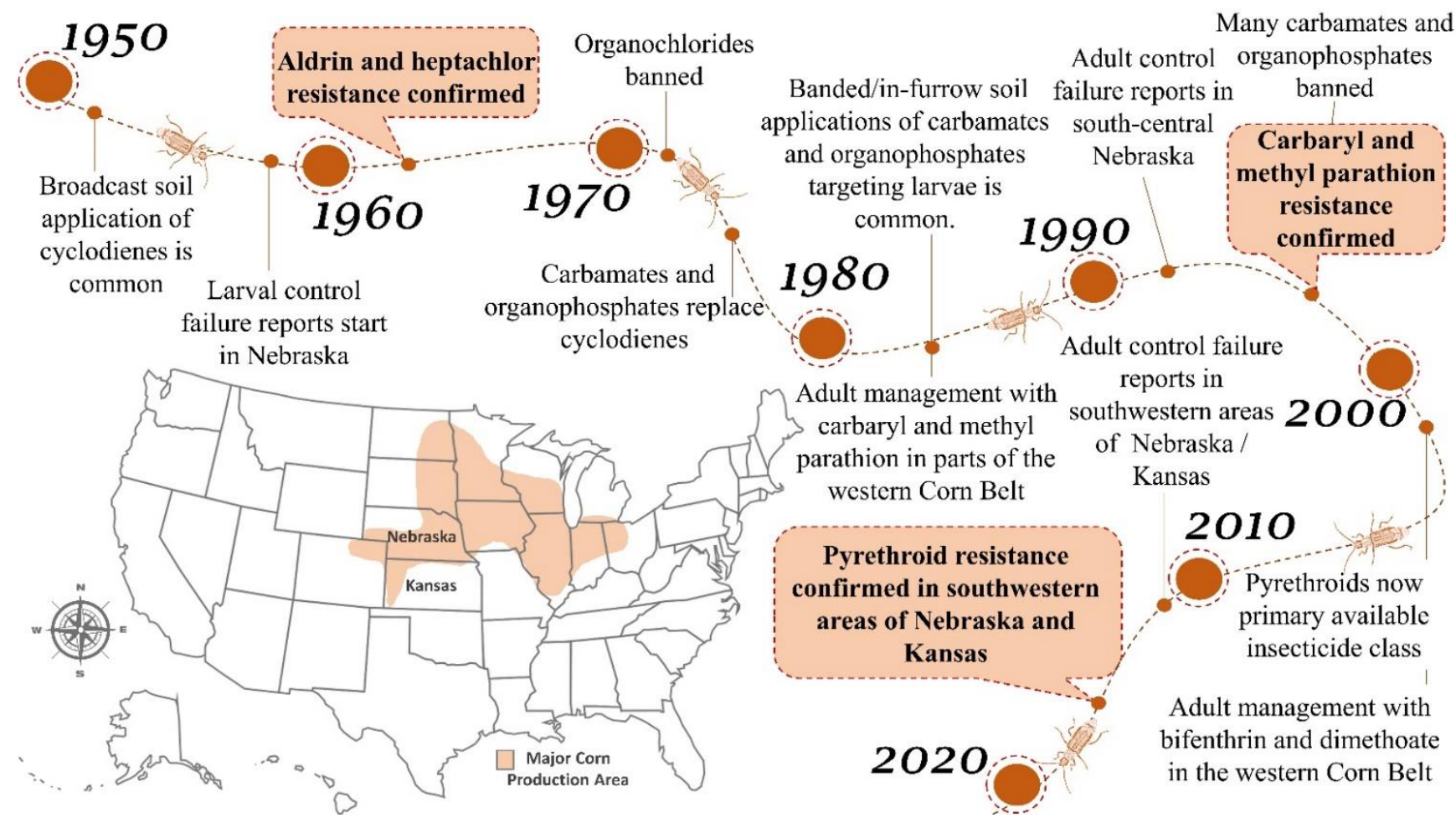

Figure 2. The agricultural region in the midwestern U.S. that is a major producer of maize is called the Corn Belt. This figure shows the major maize grain production area within this region, a Dvv insecticide use/field-evolved resistance timeline associated with continuous maize, and the geographic location of states Nebraska and Kansas where Dvv resistance to multiple insecticides has occurred. Maize grain production area is based on USDA-NASS 2015-2019 data [42,43].

\section{Western Corn Rootworm-Insecticide History}

\subsection{Soil Insecticides}

The use of soil insecticides to manage Dvv in field maize was first demonstrated by Hill et al. (1948) [23] and Muma et al. (1949) [29] in Nebraska. Broadcast planting-time applications of the chlorinated hydrocarbons DDT and the gamma isomer of benzene hexachloride (BHC) were initially evaluated. BHC (lindane) significantly reduced Dvv larval densities, plant lodging caused by larval Dvv feeding, and in some trials, increased yield when compared to untreated maize. Soil application of DDT was found to be comparatively ineffective. Muma et al. (1949) [29] also reported that BHC persisted in the soil providing Dvv control the following season after initial application. In subsequent years, cyclodienes were shown to have activity against Dvv larvae [44] and along with BHC were recommended to growers for larval control (aldrin, chlordane: [45]; heptachlor: [46]). Large-scale broadcast soil applications of BHC and cyclodiene insecticides were commonly made to field maize during the 1950s. By 1959, almost 1000 metric tons of aldrin had been applied as a soil insecticide in Nebraska alone [47].

Ineffective control of Dvv larvae after application of a soil insecticide was initially observed in south-central Nebraska in 1959 [48]. The rapid development and continuance of the problem became more apparent by 1960-1961 [49-51]. In lab bioassays, LD50s of a Dvv population from a control failure area of south-central Nebraska were 78.8 and 43.2-fold greater for heptachlor and aldrin, respectively, than a population in eastern Nebraska 
where no larval control issues had been observed [52]. This was the first direct evidence of field-evolved resistance in Dvv to an insecticide. A follow-up study documented that susceptibility of Dvv to aldrin was highly correlated with previous insecticide use patterns in Nebraska. The LD50s of populations from high insecticide use areas around the Platte River Valley were up to 1000-fold greater than some populations from far western NE where little soil insecticide had been used [53].

Cyclodiene resistance in Dvv populations was limited to the western U.S. Corn Belt at this time because the eastern Dvv expansion across the U.S had only reached the NebraskaIowa border by 1954 [54] and western Wisconsin by 1964 [18]. Cyclodiene resistance spread throughout the existing Dvv range and was maintained in Dvv populations as the range expansion across the U.S. Corn Belt progressed. Populations along the expanding species boundary exhibited similar resistance levels to cyclodienes by 1964 [55] and high levels of resistance were present in the eastern U.S. during the 1980s even in areas where cyclodienes were not widely used before removal from the market by the U.S. Environmental Protection Agency (USEPA) in the 1970s [56]. Metcalf (1986) [57,58] noted that the rate of geographic spread was slower before than right after resistance evolved to cyclodiene insecticides. Metcalf inferred that a behavioral change associated with resistance may have led to increased movement of the range expansion front $[57,58]$. This hypothesis turned out to be unsupported as Dvv exhibited stratified dispersal with wide variation in rate of expansion depending on location and year [18].

Following widespread Dvv resistance to the environmentally persistent cyclodiene insecticides, there was a concentrated effort by state, federal, and industry scientists to discover and commercialize new insecticides with activity against Dvv [33]. Chlorinated hydrocarbon and cyclodiene insecticides were gradually removed from commercial use by regulation in the U.S. and replaced by organophosphate and carbamate insecticides [59]. The replacement insecticide classes were highly toxic, more expensive, and had shorter residual activity than the cyclodienes [33,59]. A shift from broadcast soil applications to applications banded over the row or placed in the seed furrow were adopted to reduce rates applied and subsequent cost [33]. Most soil-applied insecticides targeting larval Dvv are applied at planting-time, which often is $4-8$ weeks before Dvv eggs begin to hatch. Therefore, historically, many products were granular formulations that would extend residual activity. Eventually, prophylactic use of soil-applied organophosphate or carbamate insecticides at planting became the primary Dvv management approach in continuous maize throughout the U.S. Corn Belt [28]. Prophylactic applications were often made without knowledge of the pest density present, which led to some unnecessary insecticide applications [60-62]. It was not until the 1980s that several insecticides in the pyrethroid insecticide class (bifenthrin, tefluthrin) were registered as Dvv soil insecticides in the U.S. $[63,64]$.

During the 1970s to early 1990s, there were numerous studies conducted to understand environmental and agronomic factors that could impact soil insecticide efficacy and increase understanding of Dvv population dynamics when soil insecticides were used in continuous maize. Performance of insecticide applications of all classes can be inconsistent from year to year in the soil environment $[59,65]$. The response of an insecticide in soil is a complex interaction of the physicochemical properties of an insecticide, soil and environmental conditions, and the susceptibility of the target insect pest [65]. Very dry or excessively wet soils, high soil $\mathrm{pH}$, or soils with high organic matter content have all contributed to variable soil insecticide efficacy when targeting Dvv larvae [28,66-69].

Organophosphate and carbamate insecticides are biodegraded by microbiological metabolism $[59,70,71]$. This is normally viewed as a positive characteristic since it prevents persistence of insecticides in the soil over time but can negatively impact soil insect control if biodegradation occurs rapidly and reduces insecticide residual in the soil [72]. Declining Dvv control with some carbamate or organophosphate soil insecticides was reported during the 1970s-1980s after consecutive years of application [59]. A key example was the carbamate carbofuran where studies documented poor Dvv control in soil plots treated 
with carbofuran at planting for successive years versus plots with no history of carbofuran use [73]. Subsequent research determined that rapid degradation of carbofuran by soil microbes in conditioned soils led to poor control and that field-evolved resistance to carbofuran in Dvv probably was not the causative factor [74,75]. A similar scenario occurred with the organophosphate isophenphos. This soil insecticide was initially marketed as Amaze $^{\circledR}$ in 1981 but by 1983, Dvv control failures were reported from various locations in the U.S. Corn Belt in fields where the product had been used the previous year [59]. Enhanced microbial biodegradation was found to be the cause of rapid loss of isophenphos in the soil $[76,77]$ and the formulation was removed from the market soon thereafter [59]. In both of these examples, microbial degradation of the soil insecticide occurred between planting time and the Dvv egg hatch period reducing active ingredient in the soil.

Planting date and associated timing of insecticide application relative to Dvv population dynamics can also impact efficacy of soil-applied insecticides. Soil insecticides often perform better when planting date is later and insecticide application is closer to the occurrence of Dvv larvae in the field [78-80]. Before minimum or no-till practices were widely adopted, application of insecticides at cultivation during the Dvv egg hatch period was demonstrated as an alternative to planting-time applications especially when maize was planted very early in the season [81]. Reduced tillage practices do not appear to significantly impact Dvv control with soil insecticides $[28,82,83]$.

The placement of soil-applied insecticides in a band over the row or placed in the seed furrow protects the main maize root system (reduces injury, lodging) but does not manage the Dvv population $[28,83,84]$. Little to no reduction in adult Dvv emergence from soil insecticide treated plots versus untreated plots is commonly reported [83-86]. This has been attributed to survival of Dvv larvae feeding on maize roots between rows that have grown outside the treated zone and in some cases differences in larval density-dependent mortality between treatments $[83,86]$. Therefore, there is often an inconsistent relationship between soil insecticide efficacy as measured by level of root injury and subsequent adult emergence. This built-in refuge is probably a major reason why field-evolved Dvv resistance attributed to direct selection of Dvv larvae has only been documented with broadcast-applied cyclodiene insecticides but not insecticides applied in-furrow or banded over the row $[83,86,87]$.

The fitness of Dvv adults that emerge from soil insecticide treated fields is highly variable. Later mean adult emergence time, increased longevity, increased egg production, and variable sex ratios have been reported after Dvv larval exposure to organophosphate and carbamate soil insecticides [85,88-91], but results are inconsistent within products over years. Soil insecticide exposure does not appear to significantly affect egg viability $[89,90]$. Extended mean development time can also be caused by high Dvv larval densities $[89,92,93]$, therefore, the variability in Dvv life history parameters associated with soil insecticide environments may be caused by the complex interaction of Dvv density, sublethal exposure/insecticide dose, and environmental conditions.

Liquid formulations of some carbamate, organophosphate, pyrethroid, and phenylpyrazole insecticides applied at planting or during the Dvv larval period have provided an alternative to granular formulations. Many liquid formulations can be applied in-furrow in starter fertilizer at planting [31,94] or chemigated through center pivot irrigation systems to control Dvv larvae [95]. In 1996, the Food Quality Protection Act altered the regulation of pesticides in the U.S. and the USEPA canceled uses of a number of organophosphate and carbamate insecticides, which has greatly reduced the insecticide options available for larval Dvv control.

\subsection{Seed Treatments}

The neonicotinoid insecticides thiamethoxam and clothianidin were initially registered as maize seed treatments in the early 2000s in the U.S. [96-98]. These seed treatments were primarily marketed at low rates $(0.25-0.5 \mathrm{mg} / \mathrm{seed})$ to control seedling maize insect pests and were quickly adopted by the seed industry. Today, most field-maize seed 
planted in the U.S. is treated with a low-rate neonicotinoid insecticide [39,99]. A higher rate $(1.25 \mathrm{mg} / \mathrm{seed})$ of thiamethoxam or clothianidin has been marketed for Dvv control. Clothianidin is very toxic to Dvv neonate larvae and some natural variability in susceptibility occurs among Dvv populations [100]. Field trial data consistently show that the $1.25 \mathrm{mg} /$ seed neonicotinoid rate provides effective maize root protection when Dvv densities are low to moderate but protection is reduced under high Dvv larval densities [101,102]. To date there have not been any reports of field-evolved Dvv resistance to neonicotinoids deployed as seed treatments [102]. The future of neonicotinoids as seed treatments is unclear as environmental and nontarget concerns [103-106] have led to neonicotinoid bans in the European Union, restrictions in Canada, and a formal review of use in the U.S. [107-109]. Questions have also been raised as to whether an insecticidal seed treatment is necessary in all field situations because of the sporadic nature of many seedling pests [110]. Therefore, there is a need for greater understanding of actual pest pressure applied by the seedling pest complex in various crops/regions, methodology to assess the risk posed by seedling pests, and where appropriate, alternative technologies or strategies that can effectively protect seeds and seedlings from arthropods [110,111].

\subsection{Foliar Insecticides}

The application of foliar insecticides to suppress adult Dvv densities is used primarily for two purposes: (1) Protect maize during the pollination period from excessive adult Dvv silk feeding, which can interfere with pollination and result in poorly filled ears, and/or (2) reduce Dvv female density and associated oviposition to reduce potential larval injury the following season in continuous maize [112,113]. Initial experiments conducted by Hill et al. (1948) [23] demonstrated that DDT provided excellent control of adult Dvv. DDT was a key compound used to reduce Dvv silk feeding during the 1950s in Nebraska [25]. During the 1960s-1970s after field-evolved Dvv cyclodiene resistance limited larval control options, there was increasing interest in using adult foliar insecticide applications to reduce adult densities and oviposition in continuous maize fields to prevent the need for a soil insecticide the following year. Organophosphate and carbamate insecticides replaced DDT and provided control of adult Dvv $[32,34,114]$. A constraint of many products was low residual activity in the field because adequate residual activity coupled with proper application timing was needed to effectively manage rootworm densities [32]. Eventually, formulations of carbaryl (Sevin 4-Oil ${ }^{\circledR}$, used mainly during the 1970s) and encapsulated methyl parathion (Penncap-M ${ }^{\circledR}$, used primarily during 1980s-1990s) were developed that provided up to three weeks residual activity and became products of choice in many Dvv adult management programs [115]. The viable aerial application industry and the growing number of professional crop consultants led producers in some areas of south-central Nebraska to exclusively use adult control to manage Dvv in continuous maize [32,112,114].

The adult management strategy worked well in the western U.S. Corn Belt from the 1960s to early 1990s but reports of adult control failures increased during the 1990s in south-central Nebraska [115-118]. In areas where intensive use of Penncap-M ${ }^{\circledR}$ was common, both rates of application and the number of applications per season increased as a result of reduced product efficacy [115]. Topical bioassays were used to document initial 16- and 9-fold field-evolved Dvv resistance to methyl parathion and carbaryl, respectively in 1995 [115], and vial bioassays were developed to monitor changes in geographical distribution of Dvv resistance in Nebraska over time [117,119,120]. Initially, Dvv resistance centered around two distinct focal areas separated by about $145 \mathrm{~km}$ in south central NE; Phelps/Kearney Counties and York County [117]. Dvv populations collected in counties between the focal areas were highly susceptible to methyl parathion suggesting that resistance may have evolved independently in each area. From 1996 to 2001, resistance intensity increased and areas between the initial focal areas previously identified as susceptible became highly resistant expanding the distribution of resistant Dvv populations throughout the Platte River Valley [121]. The use of adult control as a stand-alone Dvv management strategy gradually was abandoned during the late 1990s-2000s in Nebraska. 
Research on the chemical ecology of Diabrotica species during the 1980s identified a variety of Diabrotica semiochemicals that provided new opportunities to manage adult Dvv populations with greatly reduced rates of insecticide. Semiochemicals included a variety of plant-derived attractants [122-124] and cucurbitacins (tetracyclic triterpenoids found in many cucurbits), which are arrestants and feeding stimulants for adult Diabrotica species [125-127]. A bait-type concept was developed in which semiochemicals were used to facilitate adult Dvv location and feeding on formulations that contain minute amounts of insecticide [128-131]. Initial formulations were granular and carbaryl was often used as the insecticide because of its efficacy as a Dvv oral poison. Efficacy of granular formulations was shown to be greatly affected by bait location and vertical distribution of adult Dvv in the plant canopy. In field maize, semiochemical-based baits were very effective up in the canopy but ineffective when placed on the ground $[132,133]$. To circumvent this problem, industry developed sprayable formulations that would adhere and dry on the plant versus granules that would roll off of plant leaves. MicroFlo Company (Lakeland FL) was issued a registration in 1992 for a sprayable microsphere formulation (SLAM) that contained cucurbitacin (Cucurbita foetidissima HBK root powder) and carbaryl [134]. Broadcast aerial applications of SLAM often provided $>90 \%$ reduction of adult Dvv $24 \mathrm{~h}$ post application using only $10-13 \%$ of the active ingredient normally applied with conventional carbaryl applications $[135,136]$. Other companies subsequently developed adjuvant products that contained either $C$. foetidissima root powder (COMPEL: Scentry Inc. Billings, MT, USA; Cidetrak: Trece, Salinas, CA, USA) or bitter Hawksbury watermelon (Citrullus vulgaris Schrad.) juice (Invite: Florida Food Products, Eustis, FL, USA) that were marketed for tank mixing with very low rates of insecticide $[134,137]$.

Pruess et al. (1974) [34] demonstrated in the late 1960s that application of ULV malathion over a $41.4 \mathrm{sq} \mathrm{km}$ area could reduce adult Dvv densities so larval densities the following year would be greatly reduced and not cause economic loss. This concept was revisited in a USDA-sponsored pilot areawide management program that was conducted at four $41.4 \mathrm{sq} \mathrm{km}$ locations in the Corn Belt from 1996 to 2002 to evaluate the efficacy of the semiochemical bait SLAM to manage Dvv population densities and crop injury $[138,139]$. The program clearly demonstrated that annual use of SLAM could effectively reduce adult Dvv and subsequent larval feeding injury the following season comparable to the level of control obtained with soil insecticides. Population management of Dvv was variable across sites as annual immigration of adults into the managed area prevented long-term suppression of Dvv over time. However, at some sites, the number of fields requiring treatment was significantly reduced over years in the managed area versus control companion area. The semiochemical bait approach significantly reduced the amount of ai applied by up to 20-fold and did not significantly affect densities of nontarget insects [139,140]. Previous research had shown that cucurbitacin was actually a repellent/antifeedant to some nontarget insects so nontargets could avoid the discrete bait droplets and not consume the toxin [141].

Part of the Dvv areawide management program was a project to monitor potential shifts in susceptibility of Dvv populations during the life of the pilot program. Annual collections of adult Dvv from managed and control companion areas of each program location were bioassayed with a diagnostic concentration of carbaryl (LC99). Significant reduction in Dvv susceptibility to carbaryl was detected in three of the four managed areas and a significant reduction in the responsiveness of Dvv to cucurbitacin was also observed at the same three sites [142]. Zhu et al. (2001) [143] conducted a separate monitoring study at the Kansas location and also reported rapid changes in susceptibility to carbaryl in the managed area after selection with SLAM over years. A similar shift in susceptibility was not observed in the companion control area. These results collectively suggest that areawide programs have the potential to select for resistance and that a strategy for managing and reducing selection pressure (e.g., rotation of insecticide ai) should be implemented. When the toxicity of various insecticide semiochemical bait mixtures was evaluated comparing Dvv organophosphate resistant and susceptible populations, results indicated that bait 
efficacy may be compromised by previously identified resistance and by insecticides that antagonize the feeding stimulation of the cucurbitacin in the bait [144]. Therefore, careful selection of insecticide active ingredient should be made if rotation of insecticides in baits over time is a resistance management goal.

The semiochemical bait concept or Dvv areawide management were not widely adopted in the U.S. Corn Belt. A number of factors may have contributed to this. Only small companies with limited research budgets and sales/marketing personnel developed the commercialized bait products. Larger agrochemical companies were committed to development of transgenic plants and companion seed treatment technologies as future Dvv management tools during the 1990 's-2000's. Adult management is more knowledge and labor intensive than using a soil insecticide or planting a transgenic hybrid. In Nebraska, professional consultants are often hired to scout fields and properly time insecticide applications. Areawide programs involve a lot of organizational complexity and cooperation to uniformly apply specific management tactics over defined areas [145]. Therefore, farmers are required to relinquish some freedom to make independent insect management decisions on their farms. The end of the Dvv areawide pilot program coincided with the introduction of Dvv-active transgenic plant technologies and complementary neonicotinoid seed treatments that were quickly adopted $[39,41]$. The ability of farmers to incorporate a new technology with current practices and the perceived complexity of the innovation often impacts adoption [146]. The commercialization of transgenic plants simplified insect control by eliminating the need for soil-applied insecticides and provided excellent larval control [147]. While the semiochemical-bait concept still has merit, only a small niche market developed, and most bait or adjuvant products have been removed by industry from the market.

Since 2003, aerial or chemigated application of foliar-applied insecticides to manage arthropod pests is still commonly practiced in the western U.S. Corn Belt. However, planting of hybrids expressing Dvv-active Bacillus thuringiensis Berliner (Bt) proteins are often the centerpiece of Dvv management programs with fewer growers relying exclusively on insecticides to manage Dvv. Stand-alone adult Dvv management programs used in the 1960s-1990s have been replaced by periodic use of foliar applications to manage Dvv densities in continuous maize as a complement to other management tactics [148]. Regulatory reviews by the USEPA of older registered chemistries gradually removed many insecticides that were labelled for adult Dvv control leaving only pyrethroids and a few organophosphates as primary options. In the continuous maize system, the pyrethroid bifenthrin and organophosphate dimethoate are routinely used to manage other arthropod pests (i.e., western bean cutworm Striacosta albicosta (Smith), two-spotted spider mite Tetranychus urticae Koch, and banks grass mite Oligonychus pratensis (Banks) as well as Dvv, therefore, Dvv can receive selection pressure as a target or nontarget insect over time [148,149].

Results of active ingredient lab bioassays revealed that adult Dvv were very susceptible to bifenthrin during the 1990s in south-central Nebraska and southwestern Kansas [38,115]. However, from 2002-2014 there was a 40\% increase in the use of bifenthrin in Nebraska [150]. From 2010-2012, anecdotal reports of reduced Dvv control with bifenthrin in parts of Nebraska and Kansas became more common. Follow-up active ingredient lab adult bioassays of Dvv field collections made in 2013-2014 from the affected areas of Kansas and Nebraska detected emerging Dvv field-evolved resistance to bifenthrin [149,151]. Initial resistance ratios were relatively low for adults ( $<10$-fold), but subsequent active ingredient lab bioassays conducted with 2016 collections from the same Nebraska county as 2013-2014 collections revealed bifenthrin resistance ratios in the 4 to 55 -fold range depending on the susceptible reference population used [148]. Dimethoate active ingredient lab bioassays with the same 2016collected populations revealed a low level of Dvv resistance as well (RR: 3 to 16-fold) [148]. Indoxacarb, a recently registered insecticide labeled for Dvv adult control, was toxic to all adult Dvv populations bioassayed [148]. The bifenthrin resistance detected in the active ingredient lab bioassays was confirmed with commercial formulated bifenthrin using a simulated aerial application assay while the low level of dimethoate resistance detected in 
active ingredient bioassays was not apparent in formulated product assays [148]. This Dvv resistance problem is restricted primarily to southwestern areas of Nebraska and Kansas (and possibly northeastern Colorado).

Bifenthrin diagnostic concentration (LC99) bioassays of adult Dvv indicated that all populations tested from Corn Belt states east of Nebraska were very susceptible with increased survival in northeast NE and highest survival in southwestern areas of Kansas and Nebraska [149]. Dvv cross-resistance with the pyrethroids tefluthrin and cyfluthrin was also documented in lab bioassays [86,149]. Tefluthrin and bifenthrin are commonly used Dvv soil insecticides often applied in-furrow at planting throughout the Corn Belt while extensive use of aerial application of bifenthrin is limited to the western Corn Belt. Because resistance evolution attributed to direct selection of larvae has not been documented with soil insecticides placed in-furrow or over the row, the significant difference in Dvv susceptibility to bifenthrin between southwestern areas of Kansas and Nebraska versus geographic areas east of Nebraska strongly supports the working hypothesis that selection of adults is the main driver of observed Dvv pyrethroid resistance.

The Dvv organophosphate/carbamate resistance during the 1990s and Dvv pyrethroid resistance during the 2010s are the only known cases where the efficacy of Dvv soil insecticide active ingredients in bioassays or formulated product applied in-furrow or banded over the row was reduced by Dvv resistance [86,152]. In each case, resistance evolution was tied to selection of Dvv adults with foliar applied formulations leading to reduced efficacy of one or more soil-applied insecticides targeting larvae. Adult selection with the organophosphate methyl parathion reduced larval control efficacy with methyl parathion (not used as a soil insecticide), tefluthrin, and carbofuran [152]. The more recent pyrethroid selection of adults led to significant reductions in larval control efficacy with bifenthrin, tefluthrin, and cyfluthrin [86].

\section{Mechanisms of Dvv Resistance to Insecticides}

\subsection{Organochlorides}

The first investigations on mechanisms of Dvv cyclodiene resistance were mostly focused on comparative susceptibility levels and metabolic responses in resistant individuals. Experiments performed with field collected Dvv populations in the mid-1970s showed high levels of resistance to aldrin and heptachlor but not to other organochlorides such as DDT or methoxychlor indicating that the major selection for resistance in this species had resulted from cyclodiene soil treatments and suggested different metabolic pathways and/or modes of action between some organochloride insecticides [35]. An early investigation of in vivo insecticide detoxification mechanisms in Dvv showed that relative to organophosphates and carbamates, aldrin was very resistant to total detoxification but that it was readily converted to the more stable epoxide dieldrin [153]. Further examinations revealed a highly active cytochrome P450-dependent aldrin epoxidase system in cyclodiene resistant Dvv [154], which could not clearly explain the resistance phenotype since the epoxide dieldrin is equal to or more toxic to Dvv than the parental compound [155]. Another assessment showed that the susceptibility of Dvv to aldrin was increased by 9-fold when adults were maintained on diets other than corn suggesting that host-dependent alterations in aldrin metabolizing enzymes could contribute to the resistance mechanism [56]. Then a laboratory study demonstrated that aldrin resistant Dvv adults displayed a much higher conversion of epoxide dieldrin into aldrin trans-diol in the central nervous system relative to the whole body and also displayed cross-resistance to picrotoxinin [156], a compound thought to share a similar target site with cyclodiene insecticides $[157,158]$.

Cyclodienes mode of action involves antagonism of the $\gamma$-aminobutyric acid (GABA) receptor in the nervous system thereby suppressing inhibitory post synaptic graded potentials $[159,160]$. The GABA receptors are ligand-gated chloride channels that regulate inhibitory potentials by controlling the flux of chloride ions through nerve cell membranes, and are important targets for several insecticides [161-164]. Target site mutations in the GABA-receptor $(R d l)$ were first detected in a dieldrin resistant strain of the fruit fly 
Drosophila melanogaster Meigen [165] and then in several other insect species [163,166]. In most cases studied, cyclodiene resistance was caused by a conserved point mutation which results in an amino acid substitution of an alanine either to serine or glycine within the second transmembrane domain (M2) of the GABA-receptor $[163,166,167]$. Investigations on cyclodiene-resistant Dvv populations collected throughout the U.S. Corn Belt from 2006 to 2011 confirmed a non-synonymous single nucleotide polymorphism (SNP) G/T at the GABA receptor cDNA position 838, which resulted in the alanine to serine change [168]. Results collected from Wang et al. (2013) [168] also suggested that a phenotypic gradient of increasing resistance levels from west to east in the U.S. Corn Belt historically documented $[53,87]$ was correlated with higher frequencies of the resistance-conferring allele in the eastern-most populations.

For a period of nine years (1952-1961), the extensive use of aldrin in Nebraska provided high selection pressure over local Dvv populations and left considerable residue of this persistent organochloride and its epoxide, dieldrin, in the soil [47]. Data collected in Nebraska from 1962 through 1981 suggested a possible correlation between LD50 values for Dvv to aldrin and amounts of aldrin $(<0.01 \mathrm{ppm})$ and dieldrin $(0.02 \mathrm{ppm})$ remaining in the soils [47]. However, similarly high levels of aldrin resistance were still detected in the early 2000s in field-collected Dvv adults [87] in areas where soil samples contained residues as low as $0.002 \mathrm{ppm}$ for aldrin and $0.006 \mathrm{ppm}$ for dieldrin [169], which is likely below an effective concentration that would cause mortality even in susceptible populations. Additionally, Parimi et al. (2006) [87] found high levels of aldrin resistance in field collected Dvv populations that had been laboratory reared without insecticide exposure for 7-8 generations. Models of insecticide resistance evolution often share the central assumption that resistance is associated with a fitness cost because it involves a significant modification of a common phenotype, resistance genes generally have a low initial frequency, and resistance is rarely fixed in natural populations in the absence of selection [170-172]. Despite evidences for fitness cost associated with cyclodiene resistance in some insect species [173,174], cyclodiene resistant populations of Drosophila spp., Blattella germanica (L), and Anopheles gambiae Giles illustrate that $R d l$ mutations in the GABA-receptor can persist in the absence of selection [175-177]. The relatively high frequencies of Rdl mutations persisting in Dvv populations [168] is remarkable and may indicate lack of fitness cost associated with the resistance trait in this species [87].

\subsection{Carbamates and Organophosphates}

Carbamates and organophosphates are neurotoxins that bind to and inhibit acetylcholinesterases and prevent these enzymes from hydrolyzing the excitatory neurotransmitter, acetylcholine, thereby prolonging neuroexcitation of postsynaptic receptors in the nervous system $[178,179]$. Although both insecticide classes are acetylcholinesterase inhibitors, the pharmacokinetics of these compounds are not the same. The majority of organophosphate insecticides used for Dvv control contain the $\mathrm{P}=\mathrm{S}$ moiety (e.g., parathion) and are metabolically activated by cytochrome $\mathrm{P} 450$ monooxygenases into more toxic true phosphates (e.g., paraoxon), which forms very stable bonds with serine residues of acetylcholinesterases [180]. The process of acetylcholinesterase recovery from organophosphate binding i.e., dephosphorylation, is very slow and mortality occurs before significant recovery $[180,181]$. Carbamates are direct inhibitors of acetylcholinesterases and metabolic activation is not required [180]. Moreover, the rate of acetylcholinesterase decarbamylation is significantly faster than dephosphorylation such that carbamates are generally less effective inhibitors of acetylcholinesterase [181]. Carbamates and organophosphates are both generally apolar compounds with ester bonds and can be converted in vivo into more water soluble and less toxic metabolites by hydrolytic esterases [182,183]. Additionally, several P450-dependent oxidative processes are involved in detoxification of these insecticides [184].

The most common mechanism of carbamate and organophosphate resistance in insects is through enhanced insecticide detoxification [184], but mutations in acetylcholinesterases 
that minimize insecticide binding have also been documented [185,186]. Mechanisms involved in carbamate and organophosphate resistance in Nebraska Dvv populations exhibiting high levels of resistance to methyl parathion and carbaryl have been extensively studied. Cross-resistance has been identified not only to other organophosphates and carbamates, but also to pyrethroids, which were not used extensively in affected areas, suggesting that common metabolic pathways shared between these different insecticide classes were involved in the resistance mechanism [115,152,187]. Additional in vivo and in vitro experiments confirmed significative differences in oxidative (i.e., P450-based) and hydrolytic (i.e., esterase-based) insecticide metabolism in the resistant Dvv populations $[119,152,187,188]$ and provided collective evidence for a number of different attributes of the resistant populations.

Dvv populations with similar levels of resistance to methyl parathion and carbaryl in insecticide bioassays [115] displayed variable isoforms and activity levels of both P450s and esterases suggesting that resistance mechanisms were different among the populations examined [187]. Enhanced esterase activity detected in resistant Dvv populations was involved in more efficient detoxification of both methyl parathion and carbaryl $[187,188]$. P450-dependent bioactivation of methyl parathion into the more toxic metabolite methyl paraoxon was consistently reduced among resistant populations and in combination with enhanced esterase activity conferred high resistance levels [187]. Cytochrome P450dependent $\mathrm{N}$-demethylation was enhanced in at least one resistant Dvv population and was a primary metabolic event involved in carbaryl detoxification [188]. Both methyl parathion and carbaryl resistance that was selected in Dvv adults conferred resistance to larvae but did not result in equal cross-resistance to soil-applied O-ethyl-substituted organophosphates (terbufos and chlorpyrifos) and carbamates (carbofuran) [152]. Enhanced esterase activity was the most consistent resistance mechanism identified among both adult and larval stages, and cross-resistance with pyrethroids was higher in Dvv larvae (tefluthrin) than in adults (bifenthrin) $[115,152]$. The complexity of these results indicates that it is probably inappropriate to generalize a common Dvv resistance mechanism although common attributes of enhanced metabolic detoxification were detected.

Further investigations of the organophosphate- and carbamate-resistant Dvv identified through Northern blotting experiments revealed higher expression of CYP4 P450 genes in Dvv populations that were significantly resistant to methyl parathion and carbaryl [189]. In addition, three distinct esterase isozyme groups were identified in Dvv and the activity of a specific group of esterase isozymes (group II) was consistently higher in all resistant Dvv populations [190]. The activities of these isozymes based on native gel electrophoresis were identified as a reliable marker for detection of resistance [120]. Purification and characterization of group II esterases demonstrated that they were present in all Dvv populations, but were overproduced in resistant phenotypes indicating quantitative genetic differences rather than qualitative changes in physical chemical properties of these enzymes [191]. Reciprocal crosses of resistant Dvv populations then revealed that inheritance of methyl parathion resistance was not exclusively correlated with inheritance of elevated esterase activity [192] confirming earlier findings that additional factors other than just enhanced hydrolytic metabolism were involved in the resistance, such as differential P450-mediated oxidation [187-189]. Similar to cyclodiene resistance, Dvv resistance levels to methyl parathion remained relatively stable over many years in the absence of selection in both laboratory and field populations suggesting lack of fitness cost associated with the resistance trait and persistence of correspondent resistance alleles [87]. However, it is unclear whether there is a lack of fitness cost or if the univoltine life cycle prevented/delayed the fitness cost to manifest.

\subsection{Pyrethroids}

The pyrethroid insecticide class includes neurotoxins that bind and disrupt voltagegated sodium channels associated with axonal transmission [193-195], although voltagegated calcium and chloride channels have also been identified as secondary targets [196-201]. 
Once pyrethroids bind to sodium channels, axons experience a higher influx of sodium ions, prolonged sodium inactivation and repetitive electrical discharges that disrupt the normal flow of information through the central nervous system [202]. Pyrethroids are generally divided into two classes based on the symptomology, and by the presence or absence of an $\alpha$-cyano group in the molecular structure. Type I compounds (e.g., permethrin, tefluthrin, bifenthrin) are characterized by causing restlessness, incoordination, and prostration, whereas Type II (e.g., deltamethrin, $\lambda$-cyhalothrin, $\beta$-cyfluthrin) contain an $\alpha$-cyano group in the molecule structure and cause incoordination, convulsions, and intense hyperactivity $[200,203,204]$. Although this distinction among the two subclasses exists, it is possible to find some pyrethroids exhibiting intermediate properties [203-206].

Multiple studies in different insect species have shown that enhanced activity of some cytochrome P450s, glutathione $S$-transferases and esterases can provide more efficient pyrethroid detoxification in resistant insects, while sodium channel mutations $(k d r)$ can affect the binding of these insecticides to the target site [184,207-209]. Lab bioassays have demonstrated that Dvv resistance to bifenthrin is partially suppressed by inhibitors of esterases and P450s, and that bifenthrin resistant Dvv populations are cross-resistant to a soil applied pyrethroid (tefluthrin) and to the organochloride DDT [151]. DDT was banned and no longer used in the U.S. since the early 1970s, but it targets the voltage gated sodium channels similarly to pyrethroids making it useful to diagnose potential target site mutations in cross-resistance lab bioassays [210-212]. Interestingly, Dvv resistance to DDT has not been previously reported. The initial screening for mechanisms of Dvv pyrethroid resistance suggested that both enhanced metabolism and sodium channel mutations could be involved in the resistance trait [151].

Further investigations revealed that bifenthrin- and tefluthrin-resistant Dvv populations also showed resistance to a Type II pyrethroid (cyfluthrin), reduced susceptibility to the organophosphate dimethoate, and increased susceptibility to the oxadiazine indoxacarb [86,148]. Pyrethroids, carbamates, and organophosphates all possess ester bonds and can be detoxified by the same hydrolytic enzymes [182,183]. Conversely, indoxacarb becomes more toxic through esterase/amidase hydrolytic bioactivation [213-215]. Therefore, reduced efficacy of the organophosphate dimethoate and negative cross-resistance with indoxacarb observed in pyrethroid-resistant Dvv populations [148] suggested enhanced hydrolytic enzyme activity as has been reported in other insect species [216-220]. A biochemical evaluation of total protein collected from Dvv adults confirmed significantly higher activity of esterases and P450s in pyrethroid-resistant Dvv populations [221] supporting previous work that suggested the involvement of these enzyme groups in the resistance trait $[148,151]$.

Laboratory selection of insecticide resistant populations is often used to examine the genetic basis of resistance, such as mechanisms, heritability, and time for resistance development [222-224]. Laboratory selection of a pyrethroid-resistant Dvv population demonstrated a major genetic contribution to the resistant phenotype and suggested that pyrethroid resistance evolution may occur rapidly in this species ( $\sim 7$ generations) under continuous adult selection [221]. Toxicological and biochemical comparisons between lab-selected and field-derived pyrethroid resistant individuals suggested that variable esterase and P450 isoforms/activity may be selected across Dvv populations showing similar levels of resistance $[148,221]$. RNA-seq gene expression analysis confirmed major overexpression of several CYP6 P450s in pyrethroid resistant Dvv populations, possible contribution of proteins with nervous system functions, and that enhanced activity of esterases previously detected could be a qualitative difference rather than quantitative [225]. However, $k d r$ sodium channel mutations were not detected in pyrethroid resistant Dvv populations suggesting that pyrethroid resistance and DDT cross-resistance observed in Dvv populations is not associated with target site insensitivity [221,225]. 


\section{Conclusions}

The history of insecticide use to manage Dvv clearly reveals a common thread among all documented cases of Dvv resistance evolution, namely population management. The broadcast cyclodiene soil applications and the organophosphate, carbamate, and pyrethroid foliar applications all exposed a large part of the target Dvv population to some level of toxicant without any structured refuge. This combined with repeated use of the same insecticides over Dvv generations led to field-evolved resistance. The structure of agricultural enterprises in the western Corn Belt (large irrigated monocultures, continuous maize, strong aerial application and livestock industries) has led to a tradition of extensive foliar insecticide use over time to manage relatively high annual densities of Dvv and other secondary insect pests. This has contributed to the sequential occurrence of Dvv resistance evolution to different active ingredients not observed in other parts of the U.S. Corn Belt. The history of Dvv resistance to insecticides illustrates the contrasting selection intensity that insecticide application strategies may provide to different life stages of insect pests and shows that insecticide resistance may evolve quickly in field populations if adequate insecticide resistance management practices are not adopted. Dvv cross-resistance to different insecticide classes and long persistence of insecticide resistance mechanisms even in the absence of selection exemplifies how levels of resistance estimated in the laboratory can have variable practical implications on the field efficacy of formulated insecticides.

In the transgenic era, foliar insecticides will still be used as a tool to prevent excessive Dvv silk-clipping when needed, especially in seed production fields. The stand-alone adult management programs are no longer recommended partly because many longer residual insecticide products have been removed from the market and the adult emergence and oviposition periods associated with transgenic seed blends ("refuge in the bag") are extended after sublethal exposure to Cry toxins in transgenic plants [226-229]. This makes it difficult to obtain the required level of oviposition suppression to prevent economic injury the following season without applying multiple adult insecticide applications. A key message from the Dvv insecticide use story presented in this review is that more holistic Dvv management strategies are needed, which combine and rotate multiple tactics at the farm level. Foliar and soil insecticides still have a place as complementary tactics with crop rotation, conventional and transgenic hybrids, and potentially biological control (e.g., nematodes $[230,231]$ ) if used within an integrated pest management framework to manage annual densities/crop injury and resistance over time [41,232]. History has clearly documented that Dvv is highly adaptable to selection pressure from management tactics $[52,115,149,233-235]$ so the probability of selecting for field-evolved resistance to any future Dvv control technology will be high if it is repeatedly used as a stand-alone management tactic.

Author Contributions: Conceptualization and writing project administration, L.J.M.; writing, reviewing, and editing, L.J.M., D.S., and B.D.S. All authors have read and agreed to the published version of the manuscript.

Funding: This was partially supported by The Nebraska Agricultural Experiment Station with funding from the Hatch Act (Accession Number 1007272) through the USDA National Institute of Food and Agriculture.

Institutional Review Board Statement: Not applicable.

Informed Consent Statement: Not applicable.

Data Availability Statement: Data sharing is not applicable to this article as new data were not created or analyzed.

Acknowledgments: The authors thank Emily E. Reinders for assistance with manuscript formatting.

Conflicts of Interest: The authors declare no conflict of interest. 


\section{References}

1. Sappington, T.W.; Siegfried, B.D.; Guillemaud, T. Coordinated Diabrotica genetics research: Accelerating progress on an urgent insect pest problem. Am. Entomol. 2006, 52, 90-97. [CrossRef]

2. Wechsler, S.; Smith, D. Has resistance taken root in U.S. corn fields? Demand for insect control. Am. J. Agric. Econ. 2018, 100, 1136-1150. [CrossRef]

3. Branson, T.F.; Ortman, E.E. Host range of larvae of the western corn rootworm. J. Econ. Entomol. 1967, 60, 201-203. [CrossRef]

4. Branson, T.F.; Ortman, E.E. The host range of larvae of the western corn rootworm: Further studies. J. Econ. Entomol. 1970, 63, 800-803. [CrossRef]

5. Branson, T.F. Resistance in the grass tribe Maydeae to larvae of the western corn rootworm. Ann. Entomol. Soc. Am. 1971, 64, 861-863. [CrossRef]

6. Clark, T.L.; Hibbard, B.E. Comparison of nonmaize hosts to support western corn rootworm (Coleoptera: Chrysomelidae) larval biology. Environ. Entomol. 2004, 33, 681-689. [CrossRef]

7. Oyediran, I.O.; Hibbard, B.E.; Clark, T.L. Prairie grasses as hosts of the western corn rootworm (Coleoptera: Chrysomelidae). Environ. Entomol. 2004, 33, 740-747. [CrossRef]

8. Moeser, J.; Vidal, S. Do Alternative host plants enhance the invasion of the maize pest Diabrotica virgifera virgifera (Coleoptera: Chrysomelidae, Galerucinae) in Europe? Environ. Entomol. 2004, 33, 1169-1177. [CrossRef]

9. Campbell, L.A.; Meinke, L.J. Seasonality and adult habitat use by four Diabrotica species at prairie-corn interfaces. Environ. Entomol. 2006, 35, 922-936. [CrossRef]

10. Moeser, J.; Hibbard, B.E. A synopsis of the nutritional ecology of larvae and adults of Diabrotica virgifera virgifera (LeConte) in the new and old world-Nouvelle cuisine for the invasive maize pest Diabrotica virgifera virgifera in Europe? In Western Corn Rootworm: Ecology and Management; Vidal, S., Kuhlmann, U., Edwards, C.R., Eds.; CABI Publishing: Wallingford, UK, 2005; pp. 41-65.

11. Branson, T.F.; Krysan, J.L. Feeding and oviposition behavior and life cycle strategies of Diabrotica: An evolutionary view with implications for pest management. Environ. Entomol. 1981, 10, 826-831. [CrossRef]

12. Prystupa, B.; Ellis, C.R.; Teal, P.E.A. Attraction of adult Diabrotica (Coleoptera: Chrysomelidae) to corn silks and analysis of the host-finding response. J. Chem. Ecol. 1988, 14, 635-651. [CrossRef] [PubMed]

13. Naranjo, S.E. Flight orientation of Diabrotica virgifera virgifera and D. barberi (Coleoptera: Chrysomelidae) at habitat interfaces. Ann. Entomol. Soc. Am. 1994, 87, 383-394. [CrossRef]

14. Darnell, S.J.; Meinke, L.J.; Young, L.J. Influence of corn phenology on adult western corn rootworm (Coleoptera: Chrysomelidae) distribution. Environ. Entomol. 2000, 29, 587-595. [CrossRef]

15. LeConte, J.L. New Coleoptera collected on the survey for the extension of the Union Pacific Railway, E. D. from Kansas to Fort Craig, New Mexico. In Transactions of the American Entomological Society; The Society: Philadelphia, PA, USA, 1868; Volume 2, pp. 58-59.

16. Segura-Leon, O.L. Phylogeography of Diabrotica virgifera virgifera LeConte and Diabrotica virgifera zeae Krysan and Smith (Coleoptera: Chrysomelidae). Ph.D Thesis, The University of Nebraska-Lincoln, Lincoln, NE, USA, 2004 ; pp. 1-143.

17. Lombaert, E.; Ciosi, M.; Miller, N.J.; Sappington, T.W.; Blin, A.; Guillemaud, T. Colonization history of the western corn rootworm (Diabrotica virgifera virgifera) in North America: Insights from random forest ABC using microsatellite data. Biol. Invasions 2018, 20, 665-677. [CrossRef]

18. Meinke, L.J.; Sappington, T.W.; Onstad, D.W.; Guillemaud, T.; Miller, N.J.; Komáromi, J.; Levay, N.; Furlan, L.; Kiss, J.; Toth, F. Western corn rootworm (Diabrotica virgifera virgifera LeConte) population dynamics. Agric. For. Entomol. 2009, 11, 29-46. [CrossRef]

19. Gillette, C.P. Diabrotica virgifera Lec. as a corn root-worm. J. Econ. Entomol. 1912, 5, 364-366. [CrossRef]

20. Bare, O.S. Corn Rootworm Does Damage in Southwestern Nebraska; Annual Report of Cooperative Extension Work in Agriculture and Home Economics, Entomology, State of Nebraska; The University of Nebraska-Lincoln: Lincoln, NE, USA, 1930 ; p. 21.

21. Bare, O.S. Corn Rootworms; University Nebraska Cooperative Extension Circular 1506; The University of Nebraska-Lincoln: Lincoln, NE, USA, 1931.

22. Tate, H.D.; Bare, O.S. Corn Rootworms; Bulletin of the Agricultural Experiment Station of Nebraska; The University of NebraskaLincoln: Lincoln, NE, USA, 1946; pp. 1-12.

23. Hill, R.E.; Hixson, E.; Muma, M.H. Corn rootworm control tests with benzene hexachloride DDT, nitrogen fertilizers and crop rotations. J. Econ. Entomol. 1948, 41, 392-401. [CrossRef]

24. Lilly, J.H. Soil insects and their control. Annu. Rev. Entomol. 1956, 1, 203-222. [CrossRef]

25. Ball, H.J. Larval and Adult Control Recommendations and Insecticide Resistance Data for Corn Rootworms in Nebraska (1948-1981); Department of Entomology Report; The University of Nebraska-Lincoln: Lincoln, NE, USA, 1981; pp. 1-16.

26. Wangila, D.S.; Gassmann, A.J.; Petzold-Maxwell, J.L.; French, B.W.; Meinke, L.J. Susceptibility of Nebraska western corn rootworm (Coleoptera: Chrysomelidae) populations to Bt corn events. J. Econ. Entomol. 2015, 108, 742-751. [CrossRef]

27. Gray, M.E.; Sappington, T.W.; Miller, N.J.; Moeser, J.; Bohn, M.O. Adaptation and invasiveness of western corn rootworm: Intensifying research on a worsening pest. Annu. Rev. Entomol. 2009, 54, 303-321. [CrossRef]

28. Levine, E.; Oloumi-Sadeghi, H. Management of diabroticite rootworms in corn. Annu. Rev. Entomol. 1991, 36, 229-255. [CrossRef]

29. Muma, M.H.; Hill, R.E.; Hixson, E. Soil treatments for corn rootworm control. J. Econ. Entomol. 1949, 42, 822-824. [CrossRef] 
30. Munson, J.D.; Hill, R.E. Insecticides applied at planting time for control of corn rootworm larvae in Nebraska. J. Econ. Entomol. 1970, 63, 1614-1617. [CrossRef]

31. Mayo, Z.B. A Five-Year Comparison of Insecticides Applied to Control Larvae of Western and Northern Corn Rootworms; Agricultural Experiment Station, University of Nebraska-Lincoln: Lincoln, NE, USA, 1975; pp. 1-15.

32. Mayo, Z.B. Aerial Suppression of Rootworm Adults for Larval Control; Agricultural Experiment Station, University of NebraskaLincoln: Lincoln, NE, USA, 1976; pp. 1-12.

33. Mayo, Z.B. Field evaluation of insecticides for control of larvae of corn rootworms. In Methods for the Study of Pest Diabrotica; Springer Series in Experimental Entomology; Springer: New York, NY, USA, 1986; pp. 183-203. ISBN 978-1-4612-9338-5.

34. Pruess, K.P.; Witkowski, J.F.; Raun, E.S. Population suppression of western corn rootworm by adult control with ULV malathion. J. Econ. Entomol. 1974, 67, 651-655. [CrossRef]

35. Chio, H.; Chang, C.-S.; Metcalf, R.L.; Shaw, J. Susceptibility of four species of Diabrotica to insecticides. J. Econ. Entomol. 1978, 71, 389-393. [CrossRef]

36. Sutter, G.R. Comparative toxicity of insecticides for corn rootworm (Coleoptera: Chrysomelidae) larvae in a soil bioassay. J. Econ. Entomol. 1982, 75, 489-491. [CrossRef]

37. Fuller, B.W.; Boetel, M.A.; Walgenbach, D.D.; Grundler, J.A.; Hein, G.L.; Jarvi, K.J.; Keaster, A.J.; Landis, D.A.; Meinke, L.J.; Oleson, J.D.; et al. Optimization of soil insecticide rates for managing corn rootworm (Coleoptera: Chrysomelidae) larvae in the North Central United States. J. Econ. Entomol. 1997, 90, 1332-1340. [CrossRef]

38. Zhu, K.Y.; Wilde, G.E.; Sloderbeck, P.E.; Buschman, L.L.; Higgins, R.A.; Whitworth, R.J.; Bowling, R.A.; Starkey, S.R.; He, F. Comparative susceptibility of western corn rootworm (Coleoptera: Chrysomelidae) adults to selected insecticides in Kansas. J. Econ. Entomol. 2005, 98, 2181-2187. [CrossRef]

39. Douglas, M.R.; Tooker, J.F. Large-scale deployment of seed treatments has driven rapid increase in use of neonicotinoid insecticides and preemptive pest management in U.S. field crops. Environ. Sci. Technol. 2015, 49, 5088-5097. [CrossRef]

40. USEPA. Current \& Previously Registered Section 3 PIP Registrations. Available online: https://www3.epa.gov/pesticides/ chem_search/reg_actions/pip/pip_list.htm (accessed on 16 December 2020).

41. Andow, D.A.; Pueppke, S.G.; Schaafsma, A.W.; Gassmann, A.J.; Sappington, T.W.; Meinke, L.J.; Mitchell, P.D.; Hurley, T.M.; Hellmich, R.L.; Porter, R.P. Early detection and mitigation of resistance to Bt maize by western corn rootworm (Coleoptera: Chrysomelidae). J. Econ. Entomol. 2016, 109, 1-12. [CrossRef]

42. USDA-NASS. United States: Corn Production. Available online: https://ipad.fas.usda.gov/rssiws/al/crop_production_maps/ us/USA_Corn_Total_Lev2_Prod.png (accessed on 30 December 2020).

43. USDA-NASS. Corn for Grain 2019 Production by County for Selected States. Available online: https: / /www.nass.usda.gov / Charts_and_Maps/Crops_County/cr-pr.php (accessed on 30 December 2020).

44. Cox, H.C.; Lilly, J.H. Chemical control of the corn rootworm. J. Econ. Entomol. 1953, 46, 217-224. [CrossRef]

45. Ball, H.J.; Hill, R.E. You can control corn rootworm. Neb. Exp. Stn. Quart. 1953, 1, 3-4.

46. Ball, H.J.; Roselle, R.E. You Can Control Corn Rootworms; University Nebraska College of Agricultural Extension Circular; University of Nebraska-Lincoln: Lincoln, NE, USA, 1954.

47. Ball, H.J. Aldrin and dieldrin residues in Nebraska soils as related to decreasing LD50 values for the adult western corn rootworm-1962-1981. J. Environ. Sci. Health B 1983, 18, 735-744. [CrossRef]

48. Roselle, R.E.; Anderson, L.W.; Simpson, R.C.; Webb, M.C. Annual Report for 1959; Cooperative Extension Work in Entomology; University of Nebraska-Lincoln: Lincoln, NE, USA, 1959.

49. Roselle, R.E.; Anderson, L.W.; Simpson, R.C.; Bergman, P.W. Annual Report for 1960; Cooperative Extension Work in Entomology; University of Nebraska-Lincoln: Lincoln, NE, USA, 1960.

50. Roselle, R.E.; Anderson, L.W.; Bergman, P.W. Annual Report for 1961; Cooperative Extension Work in Entomology; University of Nebraska-Lincoln: Lincoln, NE, USA, 1961.

51. Weekman, G.T. Problem in rootworm control. Proc. North Cent. Branch Entomol. Soc. Am. 1961, 16, 32-34.

52. Ball, H.J.; Weekman, G.T. Insecticide resistance in the adult western corn rootworm in Nebraska. J. Econ. Entomol. 1962, 55, 439-441. [CrossRef]

53. Ball, H.J.; Weekman, G.T. Differential resistance of corn rootworms to insecticides in Nebraska and adjoining states. J. Econ. Entomol. 1963, 56, 553-555. [CrossRef]

54. Ball, H.J. On the biology and egg-laying habits of the western corn rootworm. J. Econ. Entomol. 1957, 50, 126-128. [CrossRef]

55. Hamilton, E.W. Aldrin resistance in corn rootworm beetles. J. Econ. Entomol. 1965, 58, 296-300. [CrossRef]

56. Siegfried, B.D.; Mullin, C.A. Influence of alternative host plant feeding on aldrin susceptibility and detoxification enzymes in western and northern corn rootworms. Pestic. Biochem. Physiol. 1989, 35, 155-164. [CrossRef]

57. Metcalf, R.L. Foreword. In Methods for the Study of Pest Diabrotica; Krysan, J.L., Miller, T.A., Eds.; Springer: New York, NY, USA, 1986; pp. vii-xv.

58. Metcalf, R.L. The ecology of insecticides and the chemical control of insects. In Ecological Theory and Integrated Pest Management Practice; Kogan, M., Ed.; Wiley: New York, NY, USA, 1986; pp. 251-297.

59. Felsot, A.S. Enhanced biodegradation of insecticides in soil: Implications for agroecosystems. Ann. Rev. Entomol. 1989, 34, 453-476. [CrossRef] 
60. Turpin, F.T.; Thieme, J.M. Impact of soil insecticide usage on corn production in Indiana: 1972-19741. J. Econ. Entomol. 1978, 71, 83-86. [CrossRef]

61. Stamm, D.E.; Mayo, Z.B.; Campbell, J.B.; Witkowski, J.F.; Andersen, L.W.; Kozub, R. Western corn rootworm (Coleoptera: Chrysomelidae) beetle counts as a means of making larval control recommendations in Nebraska. J. Econ. Entomol. 1985, 78, 794-798. [CrossRef]

62. Gray, M.E.; Steffey, K.L.; Oloumi-Sadeghi, H. Participatory on-farm research in Illinois cornfields: An evaluation of established soil insecticide rates and prevalence of com rootworm (Coleoptera: Chrysomelidae) injury. J. Econ. Entomol. 1993, 86, 1473-1482. [CrossRef]

63. USEPA. EPA Pesticide Fact Sheet: Tefluthrin. Available online: https://nepis.epa.gov/Exe/ZyPDF.cgi/P100XZAX.PDF?Dockey= P100XZAX.PDF (accessed on 16 December 2020).

64. Johnson, M.; Luukinen, B.; Gervais, J.; Buhl, K.; Stone, D. Bifenthrin General Fact Sheet; National Pesticide Information Center, Oregon State University Extension Services: Corvallis, OR, USA, 2010.

65. Harris, C.R. Factors influencing the effectiveness of soil insecticides. Annu. Rev. Entomol. 1972, 17, 177-198. [CrossRef]

66. Mayo, Z.B. Influences of rainfall and sprinkler irrigation on the residual activity of insecticides applied to corn for control of adult western corn rootworm (Coleoptera: Chrysomelidae). J. Econ. Entomol. 1984, 77, 190-193. [CrossRef]

67. Sutter, G.R.; Gustin, R.D. Environmental factors influencing corn rootworm biology and control. In Proceedings of the Illinois Agricultural Pesticides Conference; University of Illinois Cooperative Extension Service: Urbana-Champaign, IL, USA, 1989; pp. $43-48$.

68. Sutter, G.R.; Branson, T.F.; Fisher, J.R.; Elliott, N.C.; Jackson, J.J. Effect of insecticide treatments on root damage ratings of maize in controlled infestations of western corn rootworms (Coleoptera: Chrysomelidae). J. Econ. Entomol. 1989, 82, 1792-1798. [CrossRef]

69. Riedell, W.E.; Sutter, G.R. Soil moisture and survival of western corn rootworm larvae in field plots. J. Kans. Entomol. Soc. 1995, $68,80-84$.

70. Gorder, G.W.; Dahm, P.A.; Tollefson, J.J. Carbofuran persistence in cornfield soils. J. Econ. Entomol. 1982, 75, 637-642. [CrossRef]

71. Harris, C.R.; Chapman, R.A.; Harris, C.; Tu, C.M. Biodegradation of pesticides in soil: Rapid induction of carbamate degrading factors after carbofuran treatment. J. Environ. Sci. Health B 1984, 19, 1-11. [CrossRef]

72. Walker, A.; Suett, D.L. Enhanced degradation of pesticides in soil: A potential problem for continued pest, disease and weed control. Asp. Appl. Biol. 1986, 12, 95-103.

73. Tollefson, J.J. Accelerated degradation of soil insecticides used for corn rootworm control. In Proceedings of the British Crop Protection Conference Pests and Diseases, Brighton Metropole, UK, 17-20 November 1986; pp. 1131-1136.

74. Williams, I.H.; Pepin, H.S.; Brown, M.J. Degradation of carbofuran by soil microorganisms. Bull. Environ. Contam. Toxicol. 1976, 15, 244-249. [CrossRef]

75. Felsot, A.S.; Wilson, J.G.; Kuhlman, D.E.; Steffey, K.L. Rapid dissipation of carbofuran as a limiting factor in corn rootworm (Coleoptera: Chrysomelidae) control in fields with histories of continous carbofuran use. J. Econ. Entomol. 1982, 75, 1098-1103. [CrossRef]

76. Abou-Assaf, N.; Coats, J.R.; Gray, M.E.; Tollefson, J.J. Degradation of isofenphos in cornfields with conservation tillage practices. J. Environ. Sci. Health B 1986, 21, 425-446. [CrossRef]

77. Racke, K.D.; Coats, J.R. Enhanced degradation of isofenphos by soil microorganisms. J. Agric. Food Chem. 1987, 35, 94-99. [CrossRef]

78. Hills, T.M.; Peters, D.C. Methods of applying insecticides for controlling western corn rootworm larvae. J. Econ. Entomol. 1972, 65, 1714-1718. [CrossRef]

79. Mayo, Z.B. Influence of planting dates on the efficacy of soil insecticides applied to control larvae of the western and northern corn rootworm. J. Econ. Entomol. 1980, 73, 211-212. [CrossRef]

80. Hoffmann, M.P.; Kirkwyland, J.J.; Gardner, J. Impact of western corn rootworm (Coleoptera: Chrysomelidae) on sweet corn and evaluation of insecticidal and cultural control options. J. Econ. Entomol. 2000, 93, 805-812. [CrossRef] [PubMed]

81. Mayo, Z.B.; Peters, L.L. Planting vs. cultivation time applications of granular soil insecticides to control larvae of corn rootworms in Nebraska. J. Econ. Entomol. 1978, 71, 801-803. [CrossRef]

82. Felsot, A.S.; Bruce, W.N.; Steffey, K.L. Degradation of terbufos (Counter) soil insecticide in cornfields under conservation tillage practices. Bull. Environ. Contam. Toxicol. 1987, 38, 369-376. [CrossRef]

83. Gray, M.E.; Felsot, A.S.; Steffey, K.L.; Levine, E. Planting time application of soil insecticides and western corn rootworm (Coleoptera: Chrysomelidae) emergence: Implications for long-term management programs. J. Econ. Entomol. 1992, 85, 544-553. [CrossRef]

84. Furlan, L.; Canzi, S.; Di Bernardo, A.; Edwards, C.R. The ineffectiveness of insecticide seed coatings and planting-time soil insecticides as Diabrotica virgifera virgifera LeConte population suppressors. J. Appl. Entomol. 2006, 130, 485-490. [CrossRef]

85. Boetel, M.A.; Fuller, B.W.; Evenson, P.D. Emergence of adult northern and western corn rootworms (Coleoptera: Chrysomelidae) following reduced soil insecticide applications. J. Econ. Entomol. 2003, 96, 714-729. [CrossRef] [PubMed]

86. Souza, D.; Peterson, J.A.; Wright, R.J.; Meinke, L.J. Field efficacy of soil insecticides on pyrethroid-resistant western corn rootworms (Diabrotica virgifera virgifera LeConte). Pest Manag. Sci. 2020, 76, 827-833. [CrossRef] [PubMed]

87. Parimi, S.; Meinke, L.J.; Wade French, B.; Chandler, L.D.; Siegfried, B.D. Stability and persistence of aldrin and methyl-parathion resistance in western corn rootworm populations (Coleoptera: Chrysomelidae). Crop Prot. 2006, 25, 269-274. [CrossRef] 
88. Ball, H.J.; Su, P.P. Effect of sublethal dosages of carbofuran and carbaryl on fecundity and longevity of the female western corn rootworm. J. Econ. Entomol. 1979, 72, 873-876. [CrossRef]

89. Sutter, G.R.; Branson, T.F.; Fisher, J.R.; Elliott, N.C. Effect of insecticides on survival, development, fecundity, and sex ratio in controlled infestations of western corn rootworm (Coleoptera: Chrysomelidae). J. Econ. Entomol. 1991, 84, 1905-1912. [CrossRef]

90. Boetel, M.A.; Fuller, B.W.; Chandler, L.D.; Hovland, D.G.; Evenson, P.D. Fecundity and egg viability of northern and western corn rootworm (Coleoptera: Chrysomelidae) beetles surviving labeled and reduced soil insecticide applications. J. Econ. Entomol. 1998, 91, 274-279. [CrossRef]

91. Petzold-Maxwell, J.L.; Meinke, L.J.; Gray, M.E.; Estes, R.E.; Gassmann, A.J. Effect of Bt maize and soil insecticides on yield, injury, and rootworm survival: Implications for resistance management. J. Econ. Entomol. 2013, 106, 1941-1951. [CrossRef]

92. Weiss, M.J.; Seevers, K.P.; Mayo, Z.B. Influence of western corn rootworm larval densities and damage on corn rootworm survival, developmental time, size, and sex ratio (Coleoptera: Chrysomelidae). J. Kans. Entomol. Soc. 1985, 58, $397-402$.

93. Elliott, N.C.; Sutter, G.R.; Branson, T.F.; Fisher, J.R. Effect of population density of immatures on survival and development of the western corn rootworm (Coleoptera: Chrysomelidae). J. Entomol. Sci. 1989, 24, 209-213. [CrossRef]

94. Mayo, Z.B. Control of larvae of the western and northern corn rootworm with liquid starter fertilizer-insecticide combinations and the influence of depth of placement. J. Econ. Entomol. 1977, 70, 234-236. [CrossRef]

95. Peters, L.L.; Lowry, S.R. Western corn rootworm (Coleoptera: Chrysomelidae) larval control with chlorpyrifos applied at planting time versus a post-planting chemigation application to corn growth under two different tillage systems. J. Kans. Entomol. Soc. 1991, 64, 451-454.

96. USEPA. Pesticide Fact Sheet: Clothianidin. Available online: https://www3.epa.gov/pesticides/chem_search/reg_actions/ registration/fs_PC-044309_30-May-03.pdf (accessed on 16 December 2020).

97. Beyond Pesticides Appendix B. Thiamethoxam Pesticide Registrations. 2013. Available online: https://www.beyondpesticides org/assets/media/documents/pollinators/documents/2013-03-21AppendixBThiamethoxamII.pdf (accessed on 16 December 2020).

98. Syngenta. Syngenta: Pioneering Seed Treatment Innovation. Available online: https://www.syngenta-us.com/prodrender/ imagehandler.ashx?imid=a0209de7-27cf-4e31-8d4a-10c19f3b1194\&fty=0\&et=8 (accessed on 16 December 2020).

99. Mullin, C.A.; Saunders, M.C., II; Leslie, T.W.; Biddinger, D.J.; Fleischer, S.J. Toxic and behavioral effects to Carabidae of seed treatments used on Cry3Bb1- and Cry1Ab/c-protected corn. Environ. Entomol. 2005, 34, 1626-1636. [CrossRef]

100. Magalhaes, L.C.; French, B.W.; Hunt, T.E.; Siegfried, B.D. Baseline susceptibility of western corn rootworm (Coleoptera: Chrysomelidae) to clothianidin. J. Appl. Entomol. 2007, 131, 251-255. [CrossRef]

101. Steffey, K.; Gray, M.; Estes, R. Insecticidal seed treatments and soil insecticides for corn rootworm control. In Proceedings of the Illinois Crop Protection Technology Conference; University of Illinois Extension: Urbana-Champaign, IL, USA, 2005; pp. 35-40.

102. Van Rozen, K.; Ester, A. Chemical control of Diabrotica virgifera virgifera LeConte. J. Appl. Entomol. 2010, 134, 376-384. [CrossRef]

103. Krupke, C.H.; Long, E.Y. Intersections between neonicotinoid seed treatments and honey bees. Curr. Opin. Insect Sci. 2015, 10, 8-13. [CrossRef]

104. Schaafsma, A.; Limay-Rios, V.; Baute, T.; Smith, J.; Xue, Y. Neonicotinoid insecticide residues in surface water and soil associated with commercial maize (Corn) fields in southwestern ontario. PLoS ONE 2015, 10, e0118139. [CrossRef]

105. Douglas, M.R.; Rohr, J.R.; Tooker, J.F. Neonicotinoid insecticide travels through a soil food chain, disrupting biological control of non-target pests and decreasing soya bean yield. J. Appl. Ecol. 2015, 52, 250-260. [CrossRef]

106. Wood, T.J.; Goulson, D. The environmental risks of neonicotinoid pesticides: A review of the evidence post 2013. Environ. Sci. Pollut. Res. 2017, 24, 17285-17325. [CrossRef]

107. European Commission. Neonicotinoids. 2020. Available online: https:/ / ec.europa.eu/food/plant/pesticides/approval_active_ substances/approval_renewal/neonicotinoids_en (accessed on 14 December 2020).

108. Health Canada Update on the Neonicotinoid Pesticides. 2020. Available online: https://www.canada.ca/content/dam/ hc-sc/documents / services / consumer-product-safety / reports-publications / pesticides-pest-management/fact-sheets-otherresources/update-neonicotinoid-pesticides-january-2020/neonic-update-sept2020-eng.pdf (accessed on 14 December 2020).

109. USEPA. Schedule for Review of Neonicotinoid Pesticides. Available online: https://www.epa.gov/pollinator-protection/ schedule-review-neonicotinoid-pesticides (accessed on 14 December 2020).

110. Sappington, T.W.; Hesler, L.S.; Allen, K.C.; Luttrell, R.G.; Papiernik, S.K. Prevalence of sporadic insect pests of seedling corn and factors affecting risk of infestation. J. Integr. Pest Manag. 2018, 9. [CrossRef]

111. Veres, A.; Wyckhuys, K.A.G.; Kiss, J.; Tóth, F.; Burgio, G.; Pons, X.; Avilla, C.; Vidal, S.; Razinger, J.; Bazok, R.; et al. An update of the worldwide integrated assessment (WIA) on systemic pesticides. Part 4: Alternatives in major cropping systems. Environ. Sci. Pollut. Res. 2020, 27, 29867-29899. [CrossRef] [PubMed]

112. Meinke, L.J. Adult corn rootworm management. In University of Nebraska Agricultural Research Division Miscellaneous Publication 63-C; The University of Nebraska-Lincoln: Lincoln, NE, USA, 1995.

113. Meinke, L.J. Adult Corn Rootworm Suppression: Corn Rootworm Management in the Transgenic Era. Available online: http:/ / www.plantmanagementnetwork.org/edcenter/seminars/corn/AdultRootworm/ (accessed on 20 December 2020).

114. Beardmore, B.W. Evaluation of western corn rootworm, Diabrotica virgifera LeConte, adult control on an individual field basis as an alternative to the use of soil insecticides in eastern Nebraska. Master's Thesis, University of Nebraska-Lincoln, Lincoln, NE, USA, 1975. 
115. Meinke, L.J.; Siegfried, B.; Wright, R.J.; Chandler, L. Adult susceptibility of Nebraska western corn rootworm (Coleoptera: Chrysomelidae) populations to selected insecticides. J. Econ. Entomol. 1998, 91, 594-600. [CrossRef]

116. Wright, R.J.; Meinke, L.J.; Siegfried, B.D. Corn rootworm management. In Proceedings Crop Protection Clinics; The University of Nebraska-Lincoln: Lincoln, NE, USA, 1996; pp. 45-53.

117. Meinke, L.J.; Siegfried, B.D.; Wright, R.J.; Chandler, L.D. Western corn rootworm resistance to insecticides: Current situation in Nebraska. In Proceedings of the Illinois Agricultural Pesticides Conference, Champaign, IL, USA, 8-9 January 1997; pp. 88-92.

118. Siegfried, B.D.; Meinke, L.J.; Scharf, M.E. Resistance management concerns for areawide management programs. J. Agric. Entomol. 1998, 15, 359-369.

119. Scharf, M.E.; Meinke, L.J.; Siegfried, B.D.; Wright, R.J.; Chandler, L.D. Carbaryl susceptibility, diagnostic concentration determination, and synergism for U.S. populations of western corn rootworm (Coleoptera: Chrysomelidae). J. Econ. Entomol. 1999, 92, 33-39. [CrossRef]

120. Zhou, X.; Scharf, M.E.; Parimi, S.; Meinke, L.J.; Wright, R.J.; Chandler, L.D.; Siegfried, B.D. Diagnostic assays based on esterasemediated resistance mechanisms in western corn rootworms (Coleoptera: Chrysomelidae). J. Econ. Entomol. 2002, 95, 1261-1266. [CrossRef]

121. Miller, N.J.; Guillemaud, T.; Giordano, R.; Siegfried, B.D.; Gray, M.E.; Meinke, L.J.; Sappington, T.W. Genes, Gene flow and adaptation of Diabrotica virgifera virgifera. Agric. For. Entomol. 2009, 11, 47-60. [CrossRef]

122. Anderson, J.F.; Metcalf, R.L. Identification of a volatile attractant for Diabrotica and Acalymma spp. from blossoms of Cucurbita maxima Duchesne. J. Chem. Ecol. 1986, 12, 87-699.

123. Lampman, R.L.; Metcalf, R.L.; Andersen, J.F. Semiochemical attractants of Diabrotica undecimpunctata howardi Barber, southern corn rootworm, and Diabrotica virgifera virgifera LeConte, the western corn rootworm (Coleoptera: Chrysomelidae). J. Chem. Ecol. 1987, 13, 959-975. [CrossRef]

124. Lampman, R.L.; Metcalf, R.L. Multicomponent kairomonal lures for southern and western corn rootworms (Coleoptera: Chrysomelidae: Diabrotica spp.). J. Econ. Entomol. 1987, 80, 1137-1142. [CrossRef]

125. Chambliss, O.L.; Jones, C.M. Cucurbitacins: Specific insect attractants in Cucurbitaceae. Science 1966, 153, 1392-1393. [CrossRef]

126. Metcalf, R.L. Changing role of insecticides in crop protection. Ann. Rev. Entomol. 1980, 25, 219-256. [CrossRef]

127. Metcalf, R.L.; Rhodes, A.M.; Metcalf, R.A.; Ferguson, J.; Metcalf, E.R.; Lu, P.-Y. Cucurbitacin contents and diabroticite (Coleoptera: Chrysomelidae) feeding upon Cucurbita spp. Environ. Entomol. 1982, 11, 931-937. [CrossRef]

128. Metcalf, R.L.; Ferguson, J.E.; Lampman, R.; Andersen, J.F. Dry cucurbitacin-containing baits for controlling diabroticite beetles (Coleoptera: Chrysomelidae). J. Econ. Entomol. 1987, 80, 870-875. [CrossRef]

129. Lance, D.R.; Sutter, G.R. Field-cage and laboratory evaluations of semiochemical-based baits for managing western corn rootworm (Coleoptera: Chrysomelidae). J. Econ. Entomol. 1990, 83, 1085-1090. [CrossRef]

130. Weissling, T.J.; Meinke, L.J. Potential of starch encapsulated semiochemical-insecticide formulations for adult corn rootworm (Coleoptera: Chrysomelidae) control. J. Econ. Entomol. 1991, 84, 601-609. [CrossRef]

131. Lance, D.R.; Sutter, G.R. Field tests of a semiochemical-based toxic bait for suppression of corn rootworm beetles (Coleoptera: Chrysomelidae). J. Econ. Entomol. 1992, 85, 967-973. [CrossRef]

132. Weissling, T.J.; Meinke, L.J. Semiochemical-insecticide bait placement and vertical distribution of corn rootworm (Coleoptera: Chrysomelidae) adults: Implications for management. Environ. Entomol. 1991, 20, 945-952. [CrossRef]

133. Lance, D.R.; Sutter, G.R. Semiochemical-based toxic baits for Diabrotica virgifera virgifera (Coleoptera: Chrysomelidae): Effects of particle size, location, and attractant content. J. Econ. Entomol. 1991, 84, 1861-1868. [CrossRef]

134. Meinke, L.J. Behavior-based adult corn rootworm management. In Proceedings of the 1992 Crop Pest Management Update; University of Illinois Extension: Urbana-Champaign, IL, USA, 1992; pp. 61-65.

135. Chandler, L.D. Comparison of insecticide-bait aerial application methods for management of corn rootworm (Coleoptera: Chrysomelidae). Southwest. Entomol. 1998, 23, 147-159.

136. Wilde, G.E.; Whitworth, R.J.; Shufran, R.A.; Zhu, K.Y.; Sloderbeck, P.E.; Higgins, R.A.; Buschman, L.L. Rootworm areawide management project in Kansas. J. Agric. Entomol. 1998, 15, 335-349.

137. Behle, R.W. Consumption of residue containing cucurbitacin feeding stimulant and reduced rates of carbaryl insecticide by western corn rootworm (Coleoptera: Chrysomelidae). J. Econ. Entomol. 2001, 94, 1428-1433. [CrossRef] [PubMed]

138. Chandler, L.D. Corn rootworm areawide management program: United States Department of Agriculture-Agricultural Research Service. Pest Manag. Sci. 2003, 59, 605-608. [CrossRef] [PubMed]

139. Chandler, L.D.; Coppedge, J.R.; Edwards, C.R.; Tollefson, J.J.; Wilde, G.R.; Faust, R.M. Corn rootworm areawide pest management in the midwestern USA. In Areawide Pest Management: Theory and Implementation; Koul, O., Cuperous, G., Elliott, N., Eds.; CAB International: Oxfordshire, UK, 2008; pp. 191-207.

140. Boetel, M.A.; Fuller, B.W.; Chandler, L.D.; Tollefson, J.J.; Mcmanus, B.L.; Kadakia, N.D.; Evenson, P.D.; Mishra, T.P. Nontarget arthropod abundance in areawide-managed corn habitats treated with semiochemical-based bait insecticide for corn rootworm (Coleoptera: Chrysomelidae) control. J. Econ. Entomol. 2005, 98, 1957-1968. [CrossRef]

141. Weissling, T.J.; Meinke, L.J.; Lytle, K.A. Effect of starch-based corn rootworm (Coleoptera: Chrysomelidae) baits on selected nontarget insect species: Influence of semiochemical composition. J. Econ. Entomol. 1991, 84, 1235-1241. [CrossRef] 
142. Siegfried, B.D.; Meinke, L.J.; Parimi, S.; Scharf, M.E.; Nowatzki, T.J.; Zhou, X.; Chandler, L.D. Monitoring western corn rootworm (Coleoptera: Chrysomelidae) susceptibility to carbaryl and cucurbitacin baits in the areawide management pilot program. J. Econ. Entomol. 2004, 97, 1726-1733. [CrossRef] [PubMed]

143. Zhu, K.Y.; Wilde, G.E.; Higgins, R.A.; Sloderbeck, P.E.; Buschman, L.L.; Shufran, R.A.; Whitworth, R.J.; Starkey, S.R.; He, F. Evidence of evolving carbaryl resistance in western corn rootworm (Coleoptera: Chrysomelidae) in areawide-managed cornfields in north central Kansas. J. Econ. Entomol. 2001, 94, 929-934. [CrossRef] [PubMed]

144. Parimi, S.; Meinke, L.J.; Nowatzki, T.M.; Chandler, L.D.; Wade French, B.; Siegfried, B.D. Toxicity of insecticide-bait mixtures to insecticide resistant and susceptible western corn rootworms (Coleoptera: Chrysomelidae). Crop Prot. 2003, 22, 781-786. [CrossRef]

145. Chandler, L.D.; Faust, R.M. Overview of areawide management of insects. J. Agric. Entomol. 1998, 15, 319-325.

146. Rogers, E.M. Diffusion of Innovations, 3rd ed.; Free Press: New York, NY, USA, 1983.

147. Rice, M.E. Transgenic rootworm corn: Assessing potential agronomic, economic, and environmental benefits. Plant Health Prog. 2004. [CrossRef]

148. Souza, D.; Vieira, B.C.; Fritz, B.K.; Hoffmann, W.C.; Peterson, J.A.; Kruger, G.R.; Meinke, L.J. Western corn rootworm pyrethroid resistance confirmed by aerial application simulations of commercial insecticides. Sci. Rep. 2019, 9, 6713. [CrossRef]

149. Pereira, A.E.; Wang, H.; Zukoff, S.N.; Meinke, L.J.; French, B.W.; Siegfried, B.D. Evidence of field-evolved resistance to bifenthrin in western corn rootworm (Diabrotica virgifera virgifera LeConte) populations in western Nebraska and Kansas. PLoS ONE 2015, 10, e0142299. [CrossRef] [PubMed]

150. NASS-USDA. QuickStats Ad-Hoc Query Tool. Available online: https:/ / quickstats.nass.usda.gov / (accessed on 20 December 2020).

151. Pereira, A.E.; Souza, D.; Zukoff, S.N.; Meinke, L.J.; Siegfried, B.D. Cross-resistance and synergism bioassays suggest multiple mechanisms of pyrethroid resistance in western corn rootworm populations. PLoS ONE 2017, 12, e0179311. [CrossRef] [PubMed]

152. Wright, R.J.; Scharf, M.E.; Meinke, L.J.; Zhou, X.; Siegfried, B.D.; Chandler, L.D. Larval susceptibility of an insecticide-resistant western corn rootworm (Coleoptera: Chrysomelidae) population to soil insecticides: Laboratory bioassays, assays of detoxification enzymes, and field performance. J. Econ. Entomol. 2000, 93, 7-13. [CrossRef] [PubMed]

153. Chio, H.; Metcalf, R.L. Detoxication mechanisms for aldrin, carbofuran, fonofos, phorate, and terbufos in four species of diabroticites. J. Econ. Entomol. 1979, 72, 732-738. [CrossRef]

154. Siegfried, B.D.; Mullin, C.A. Properties of a cytochrome P-450-dependent epoxidase in aldrin-resistant western corn rootworms, Diabrotica virgifera virgifera LeConte. Pestic. Biochem. Physiol. 1988, 31, 261-268. [CrossRef]

155. Hamilton, E.W. Relative toxicity of aldrin and dieldrin. J. Agric. Food Chem. 1971, 19, 863-864. [CrossRef]

156. Siegfried, B.D.; Mullin, C.A. Metabolism, penetration, and partitioning of [14C]aldrin in aldrin-resistant and susceptible corn rootworms. Pestic. Biochem. Physiol. 1990, 36, 135-146. [CrossRef]

157. Kadous, A.A.; Ghiasuddin, S.M.; Matsumura, F.; Scott, J.G.; Tanaka, K. Difference in the picrotoxinin receptor between the cyclodiene-resistant and susceptible strains of the german cockroach. Pestic. Biochem. Physiol. 1983, 19, 157-166. [CrossRef]

158. Tanaka, K.; Scott, J.G.; Matsumura, F. Picrotoxinin receptor in the central nervous system of the american cockroach: Its role in the action of cyclodiene-type insecticides. Pestic. Biochem. Physiol. 1984, 22, 117-127. [CrossRef]

159. Bloomquist, J.R.; Soderlund, D.M. Neurotoxic insecticides inhibit GABA-dependent chloride uptake by mouse brain vesicles. Biochem. Biophys. Res. Commun. 1985, 133, 37-43. [CrossRef]

160. Narahashi, T.; Frey, J.M.; Ginsburg, K.S.; Roy, M.L. Sodium and GABA-activated channels as the targets of pyrethroids and cyclodienes. Toxicol. Lett. 1992, 64-65, 429-436. [CrossRef]

161. Buckingham, S.D.; Biggin, P.C.; Sattelle, B.M.; Brown, L.A.; Sattelle, D.B. Insect GABA receptors: Splicing, editing, and targeting by antiparasitics and insecticides. Mol. Pharmacol. 2005, 68, 942-951. [CrossRef]

162. Ffrench-Constant, R.H.; Williamson, M.S.; Davies, T.G.E.; Bass, C. Ion channels as insecticide targets. J. Neurosci. 2016, 30, 163-177. [CrossRef] [PubMed]

163. Ffrench-Constant, R.H.; Anthony, N.; Aronstein, K.; Rocheleau, T.; Stilwell, G. Cyclodiene insecticide resistance: From molecular to population genetics. Ann. Rev. Entomol. 2000, 45, 449-466. [CrossRef] [PubMed]

164. Raymond-Delpech, V.; Matsuda, K.; Sattelle, B.M.; Rauh, J.J.; Sattelle, D.B. Ion channels: Molecular targets of neuroactive insecticides. Invertebr. Neurosci. 2005, 3-4, 119-133. [CrossRef]

165. Ffrench-Constant, R.H.; Roush, R.T. Cloning of a locus associated with cyclodiene resistance in Drosophila. In Molecular Mechanisms of Insecticide Resistance; ACS Symposium Series; American Chemical Society: Washington, DC, USA, 1992; Volume 505, pp. 90-98. ISBN 978-0-8412-2474-2.

166. Taylor-Wells, J.; Jones, A.K. Variations in the insect GABA receptor, RDL, and their impact on receptor pharmacology. In Advances in Agrochemicals: Ion Channels and G Protein-Coupled Receptors (GPCRs) as Targets for Pest Control; ACS Symposium Series; American Chemical Society: Washington, DC, USA, 2017; Volume 1265, pp. 1-21. ISBN 978-0-8412-3260-0.

167. Hosie, A.; Sattelle, D.; Aronstein, K.; Ffrench-Constant, R. Molecular biology of insect neuronal GABA receptors. Trends Neurosci. 1997, 20, 578-583. [CrossRef]

168. Wang, H.; Coates, B.S.; Chen, H.; Sappington, T.W.; Guillemaud, T.; Siegfried, B.D. Role of a gamma-aminobutryic acid (GABA) receptor mutation in the evolution and spread of Diabrotica virgifera virgifera resistance to cyclodiene insecticides. Insect. Mol. Biol. 2013, 22, 473-484. [CrossRef] 
169. Chen, H.; Wang, H.; Siegfried, B.D. Genetic differentiation of western corn rootworm populations (Coleoptera: Chrysomelidae) relative to insecticide resistance. Ann. Entomol. Soc. Am. 2012, 105, 232-240. [CrossRef]

170. Coustau, C.; Chevillon, C.; Ffrench-Constant, R. Resistance to xenobiotics and parasites: Can we count the cost? Trends Ecol. Evol. 2000, 15, 378-383. [CrossRef]

171. Ffrench-Constant, R.H.; Bass, C. Does resistance really carry a fitness cost? Curr. Opin. Insect Sci. 2017, 21, 39-46. [CrossRef]

172. Taylor, M.; Feyereisen, R. Molecular biology and evolution of resistance of toxicants. Mol. Biol. Evol. 1996, 13, 719-734. [CrossRef] [PubMed]

173. Mckenzie, J.A. Selection at the dieldrin resistance locus in overwintering populations of Lucilia cuprina (Wiedemann). Aust. J. Zool. 1990, 38, 493-501. [CrossRef]

174. Rowland, M. Activity and mating competitiveness of $\Gamma \mathrm{HCH} /$ dieldrin resistant and susceptible male and virgin female Anopheles gambiae and An. stephensi mosquitoes, with assessment of an insecticide-rotation strategy. Med. Vet. Entomol. 1991, 5, $207-222$. [CrossRef] [PubMed]

175. Aronstein, K.; Ode, P.; Ffrench-Constant, R.H. Direct comparison of PCR-based monitoring for cyclodiene resistance in Drosophila populations with insecticide bioassay. Pestic. Biochem. Physiol. 1994, 48, 229-233. [CrossRef]

176. Hansen, K.K.; Kristensen, M.; Jensen, K.-M.V. Correlation of a resistance-associated Rdl mutation in the german cockroach, Blattella germanica (L), with persistent dieldrin resistance in two Danish field populations. Pest Manag. Sci. 2005, 61, 749-753. [CrossRef] [PubMed]

177. Kwiatkowska, R.M.; Platt, N.; Poupardin, R.; Irving, H.; Dabire, R.K.; Mitchell, S.; Jones, C.M.; Diabaté, A.; Ranson, H.; Wondji, C.S. Dissecting the mechanisms responsible for the multiple insecticide resistance phenotype in Anopheles gambiae s.s., M Form, from Vallée Du Kou, Burkina Faso. Gene 2013, 519, 98-106. [CrossRef]

178. Aldridge, W.N. Some properties of specific cholinesterase with particular reference to the mechanism of inhibition by diethyl p-nitrophenyl thiophosphate (E 605) and analogues. Biochem. J. 1950, 46, 451-460. [CrossRef]

179. Aldridge, W.N.; Reiner, E. Enzyme Inhibitors as Substrates: Interactions of Esterases with Esters of Organophosphorus and Carbamic Acids; North-Holland Publishing Co.: Amsterdam, The Netherland, 1972.

180. Fukuto, T.R. Mechanism of action of organophosphorus and carbamate insecticides. Environ. Health Perspect. 1990, 87, $245-254$. [CrossRef]

181. Čolović, M.B.; Krstić, D.Z.; Lazarević-Pašti, T.D.; Bondžić, A.M.; Vasić, V.M. Acetylcholinesterase inhibitors: Pharmacology and toxicology. Curr. Neuropharmacol. 2013, 11, 315-335. [CrossRef]

182. Montella, I.R.; Schama, R.; Valle, D. The classification of esterases: An important gene family involved in insecticide resistanceA Review. Mem. Inst. Oswaldo Cruz 2012, 107, 437-449. [CrossRef]

183. Sogorb, M.A.; Vilanova, E. Enzymes involved in the detoxification of organophosphorus, carbamate and pyrethroid insecticides through hydrolysis. Toxicol. Lett. 2002, 128, 215-228. [CrossRef]

184. Li, X.; Schuler, M.A.; Berenbaum, M.R. Molecular mechanisms of metabolic resistance to synthetic and natural xenobiotics. Ann. Rev. Entomol. 2007, 52, 231-253. [CrossRef] [PubMed]

185. Fournier, D. Mutations of acetylcholinesterase which confer insecticide resistance in insect populations. Chem. Biol. Interact. 2005, 157-158, 257-261. [CrossRef] [PubMed]

186. Lee, S.H.; Kim, Y.H.; Kwon, D.H.; Cha, D.J.; Kim, J.H. Mutation and duplication of arthropod acetylcholinesterase: Implications for pesticide resistance and tolerance. Pestic. Biochem. Physiol. 2015, 120, 118-124. [CrossRef]

187. Miota, F.; Scharf, M.E.; Ono, M.; Marçon, P.; Meinke, L.J.; Wright, R.J.; Chandler, L.D.; Siegfried, B.D. Mechanisms of methyl and ethyl parathion resistance in the western corn rootworm (Coleoptera: Chrysomelidae). Pestic. Biochem. Physiol. 1998, 61, 39-52. [CrossRef]

188. Scharf, M.E.; Meinke, L.J.; Wright, R.J.; Chandler, L.D.; Siegfried, B.D. Metabolism of carbaryl by insecticide-resistant and -susceptible western corn rootworm populations (Coleoptera: Chrysomelidae). Pesti. Biochem. Physiol. 1999, 63, 85-96. [CrossRef]

189. Scharf, M.E.; Parimi, S.; Meinke, L.J.; Chandler, L.D.; Siegfried, B.D. Expression and induction of three family 4 cytochrome P450 $(\mathrm{CYP} 4)^{*}$ genes identified from insecticide-resistant and susceptible western corn rootworms, Diabrotica virgifera virgifera. Insect Mol. Biol. 2001, 10, 139-146. [CrossRef]

190. Zhou, X.; Scharf, M.E.; Meinke, L.J.; Chandler, L.D.; Siegfried, B.D. Characterization of general esterases from methyl parathionresistant and -susceptible populations of western corn rootworm (Coleoptera: Chrysomelidae). J. Econ. Entomol. 2003, 96, 1855-1863. [CrossRef]

191. Zhou, X.; Scharf, M.E.; Sarath, G.; Meinke, L.J.; Chandler, L.D.; Siegfried, B.D. Partial purification and characterization of a methyl-parathion resistance-associated general esterase in Diabrotica virgifera virgifera (Coleoptera: Chrysomelidae). Pestic. Biochem. Physiol. 2004, 78, 114-125. [CrossRef]

192. Parimi, S.; Scharf, M.E.; Meinke, L.J.; Chandler, L.D.; Siegfried, B.D. Inheritance of methyl-parathion resistance in Nebraska western corn rootworm populations (Coleoptera: Chrysomelidae). J. Econ. Entomol. 2003, 96, 131-136. [CrossRef]

193. Narahashi, T. Nerve membrane as a target of pyrethroids. Pestic. Sci. 1976, 7, 267-272. [CrossRef]

194. Soderlund, D.M.; Bloomquist, J.R. Neurotoxic actions of pyrethroid insecticides. Ann. Rev. Entomol. 1989, 34, 77-96. [CrossRef] [PubMed]

195. Vijverberg, H.P.M.; van der Zalm, J.M.; van den Bercken, J. Similar mode of action of pyrethroids and DDT on sodium channel gating in myelinated nerves. Nature 1982, 295, 601-603. [CrossRef] [PubMed] 
196. Breckenridge, C.B.; Holden, L.; Sturgess, N.; Weiner, M.; Sheets, L.; Sargent, D.; Soderlund, D.M.; Choi, J.-S.; Symington, S.; Clark, J.M.; et al. Evidence for a separate mechanism of toxicity for the Type I and the Type II pyrethroid insecticides. Neurotoxicology 2009, 30, S17-S31. [CrossRef] [PubMed]

197. Hildebrand, M.E.; McRory, J.E.; Snutch, T.P.; Stea, A. Mammalian voltage-gated calcium channels are potently blocked by the pyrethroid insecticide allethrin. J. Pharmacol. Exp. Ther. 2004, 308, 805-813. [CrossRef] [PubMed]

198. Lawrence, L.J.; Casida, J.E. Stereospecific action of pyrethroid insecticides on the gamma-aminobutyric acid receptor-ionophore complex. Science 1983, 221, 1399-1401. [CrossRef] [PubMed]

199. Ray, D.E.; Sutharsan, S.; Forshaw, P.J. Actions of pyrethroid insecticides on voltage-gated chloride channels in neuroblastoma cells. Neurotoxicology 1997, 18, 755-760.

200. Soderlund, D.M. Molecular mechanisms of pyrethroid insecticide neurotoxicity: Recent advances. Arch. Toxicol. 2011, 86, 165-181. [CrossRef]

201. Symington, S.B.; Clark, J.M. Action of deltamethrin on N-type (Cav2.2) voltage-sensitive calcium channels in rat brain. Pestic. Biochem. Physiol. 2005, 82, 1-15. [CrossRef]

202. Vijverberg, H.P.M.; van den Bercken, J. Neurotoxicological effects and the mode of action of pyrethroid insecticides. Crit. Rev. Toxicol. 1990, 21, 105-126. [CrossRef]

203. Gammon, D.W.; Brown, M.A.; Casida, J.E. Two classes of pyrethroid action in the cockroach. Pestic. Biochem. Physiol. 1981, 15, 181-191. [CrossRef]

204. Lawrence, L.J.; Casida, J.E. Pyrethroid toxicology: Mouse intracerebral structure-toxicity relationships. Pestic. Biochem. Physiol. 1982, 18, 9-14. [CrossRef]

205. Scott, J.G.; Matsumura, F. Evidence for two types of toxic actions of pyrethroids on susceptible and DDT-resistant german cockroaches. Pestic. Biochem. Physiol. 1983, 19, 141-150. [CrossRef]

206. Soderlund, D.M.; Clark, J.M.; Sheets, L.P.; Mullin, L.S.; Piccirillo, V.J.; Sargent, D.; Stevens, J.T.; Weiner, M.L. Mechanisms of pyrethroid neurotoxicity: Implications for cumulative risk assessment. Toxicology 2002, 171, 3-59. [CrossRef]

207. Dong, K.; Du, Y.; Rinkevich, F.; Nomura, Y.; Xu, P.; Wang, L.; Silver, K.; Zhorov, B.S. Molecular biology of insect sodium channels and pyrethroid resistance. Insect Biochem. Mol. Biol. 2014, 50, 1-17. [CrossRef] [PubMed]

208. Liu, N.; Xu, Q.; Zhu, F.; Zhang, L. Pyrethroid resistance in mosquitoes. Insect Sci. 2006, 13, 159-166. [CrossRef]

209. Soderlund, D.M.; Knipple, D.C. The molecular biology of knockdown resistance to pyrethroid insecticides. Insect Biochem. Mol. Biol. 2003, 33, 563-577. [CrossRef]

210. Brengues, C.; Hawkes, N.J.; Chandre, F.; Mccarroll, L.; Duchon, S.; Guillet, P.; Manguin, S.; Morgan, J.C.; Hemingway, J. Pyrethroid and DDT cross-resistance in Aedes aegypti is correlated with novel mutations in the voltage-gated sodium channel gene. Med. Vet. Entomol. 2003, 17, 87-94. [CrossRef]

211. Schuler, T.H.; Martinez-Torres, D.; Thompson, A.J.; Denholm, I.; Devonshire, A.L.; Duce, I.R.; Williamson, M.S. Toxicological, electrophysiological, and molecular characterisation of knockdown resistance to pyrethroid insecticides in the diamondback moth, Plutella Xylostella (L.). Pestic. Biochem. Physiol. 1998, 59, 169-182. [CrossRef]

212. Williamson, M.S.; Denholm, I.; Bell, C.A.; Devonshire, A.L. Knockdown resistance $(k d r)$ to DDT and pyrethroid insecticides maps to a sodium channel gene locus in the housefly (Musca domestica). Mol. Gen. Genet. 1993, 240, 17-22. [CrossRef]

213. Li, F.-G.; Ai, G.-M.; Zou, D.-Y.; Ji, Y.; Bao-Gen, G.; Gao, X.-W. Characterization of activation metabolism activity of indoxacarb in insects by liquid chromatography-triple quadrupole mass spectrometry. Chin. J. Anal. Chem. 2014, 42, 463-468. [CrossRef]

214. Wing, K.D.; Sacher, M.; Kagaya, Y.; Tsurubuchi, Y.; Mulderig, L.; Connair, M.; Schnee, M. Bioactivation and mode of action of the oxadiazine indoxacarb in insects. Crop Prot. 2000, 19, 537-545. [CrossRef]

215. Wing, K.D.; Schnee, M.E.; Sacher, M.; Connair, M. A novel oxadiazine insecticide is bioactivated in lepidopteran larvae. Arch Insect Biochem. Physiol. 1998, 37, 91-103. [CrossRef]

216. Bisset, J.; Rodriguez, M.; Soca, A.; Pasteur, N.; Raymond, M. Cross-resistance to pyrethroid and organophosphorus insecticides in the southern house mosquito (Diptera: Culicidae) from Cuba. J. Med. Entomol. 1997, 34, 244-246. [CrossRef]

217. Cahill, M.; Byrne, F.J.; Gorman, K.; Denholm, I.; Devonshire, A.L. Pyrethroid and organophosphate resistance in the tobacco whitefly Bemisia tabaci (Homoptera: Aleyrodidae). Bull. Entomol. Res. 1995, 85, 181-187. [CrossRef]

218. Devonshire, A.L.; Moores, G.D. A carboxylesterase with broad substrate specificity causes organophosphorus, carbamate and pyrethroid resistance in peach-potato aphids (Myzus persicae). Pestic. Biochem. Physiol. 1982, 18, 235-246. [CrossRef]

219. Gunning, R.V.; Devonshire, A.L. Negative cross resistance between indoxacarb and pyrethroids in the cotton bollworm, Helicoverpa armigera, in Australia: A tool for resistance management. In Proceedings of the BCPC International Congress, Glasgow, Scotland, UK, 10-12 November 2003; Volume 2, pp. 789-794.

220. Ramasubramanian, T.; Regupathy, A. Pattern of cross-resistance in pyrethroid-selected populations of Helicoverpa armigera Hübner (Lep., Noctuidae) from India. J. Appl. Entomol. 2004, 128, 583-587. [CrossRef]

221. Souza, D.; Jiménez, A.V.; Sarath, G.; Meinke, L.J.; Miller, N.J.; Siegfried, B.D. Enhanced metabolism and selection of pyrethroidresistant western corn rootworms (Diabrotica virgifera virgifera LeConte). Pestic. Biochem. Physiol. 2020, 164, 165-172. [CrossRef]

222. Georghiou, G.P.; Taylor, C.E. Genetic and biological influences in the evolution of insecticide resistance. J. Econ. Entomol. 1977, 70, 319-323. [CrossRef]

223. Roush, R.T.; McKenzie, J.A. Ecological genetics of insecticide and acaricide resistance. Ann. Rev. Entomol. 1987, 32, 361-380. [CrossRef] 
224. Tabashnik, B.E. Resistance risk assessment: Realized heritability of resistance to Bacillus thuringiensis in diamondback moth (Lepidoptera: Plutellidae), tobacco budworm (Lepidoptera: Noctuidae), and Colorado potato beetle (Coleoptera: Chrysomelidae). J. Econ. Entomol. 1992, 85, 1551-1559. [CrossRef]

225. Souza, D.; Siegfried, B.D.; Meinke, L.J.; Miller, N.J. Molecular characterization of western corn rootworm pyrethroid resistance. Pest Manag. Sci. 2021, 77, 860-868. [CrossRef] [PubMed]

226. Crowder, D.W.; Onstad, D.W.; Gray, M.E.; Pierce, C.M.F.; Hager, A.G.; Ratcliffe, S.T.; Steffey, K.L. Analysis of the dynamics of adaptation to transgenic corn and crop rotation by western corn rootworm (Coleoptera: Chrysomelidae) using a daily time-step model. J. Econ. Entomol. 2005, 98, 534-551. [CrossRef] [PubMed]

227. Clark, T.L.; Frank, D.L.; French, B.W.; Meinke, L.J.; Moellenbeck, D.; Vaughn, T.T.; Hibbard, B.E. Mortality impact of MON863 transgenic maize roots on western corn rootworm larvae in the field. J. Appl. Entomol. 2012, 136, 721-729. [CrossRef]

228. Hitchon, A.J.; Smith, J.L.; French, B.W.; Schaafsma, A.W. Impact of the Bt corn proteins Cry34/35Ab1 and Cry3Bb1, alone or pyramided, on western corn rootworm (Coleoptera: Chrysomelidae) beetle emergence in the field. J. Econ. Entomol. 2015, 108, 1986-1993. [CrossRef]

229. Keweshan, R.S.; Head, G.P.; Gassmann, A.J. Effects of pyramided Bt corn and blended refuges on western corn rootworm and northern corn rootworm (Coleoptera: Chrysomelidae). J. Econ. Entomol. 2015, 108, 720-729. [CrossRef]

230. Shields, E.J.; Testa, A.M.; O'Neil, W.J. Long-term persistence of native New York entomopathogenic nematode isolates across crop rotation. J. Econ. Entomol. 2018, 111, 2592-2598. [CrossRef]

231. Shields, E.J. Biological Control of Corn Rootworm with Persistent Entomopathogenic Nematodes: An Opportunity to Try Them on Your Farm. Available online: https://blogs.cornell.edu/whatscroppingup/2019/03/22/biological-control-of-corn-rootwormwith-persistent-entomopathogenic-nematodes-an-opportunity-to-try-them-on-your-farm/ (accessed on 31 December 2020).

232. USEPA. Framework to Delay Corn Rootworm Resistance. Available online: https://www.epa.gov/regulation-biotechnologyunder-tsca-and-fifra / framework-delay-corn-rootworm-resistance (accessed on 16 December 2020).

233. Levine, E.; Spencer, J.L.; Isard, S.A.; Onstad, D.W.; Gray, M.E. Adaptation of the western corn rootworm, Diabrotica virgifera virgifera LeConte (Coleoptera: Chrysomelidae), to crop rotation: Evolution of a new strain in response to a cultural management practice. Am. Entomol. 2002, 48, 94-107. [CrossRef]

234. Gassmann, A.J.; Petzold-Maxwell, J.L.; Clifton, E.H.; Dunbar, M.W.; Hoffmann, A.M.; Ingber, D.A.; Keweshan, R.S. Field-evolved resistance by western corn rootworm to multiple Bacillus thuringiensis toxins in transgenic maize. Proc. Natl. Acad. Sci. USA 2014, 111, 5141-5146. [CrossRef]

235. Reinders, J.D.; Hitt, B.D.; Stroup, W.W.; French, B.W.; Meinke, L.J. Spatial variation in western corn rootworm (Coleoptera: Chrysomelidae) susceptibility to Cry3 toxins in Nebraska. PLoS ONE 2018, 13, e0208266. [CrossRef] 